ORNL -5263

$123 / 1$

\title{
CUMEX - A Cumulative Hazard Index for Assessing Limiting Exposures to Environmental Pollutants
}
P. J. Waish
G. G. Killough
D. C. Darzyck
P. S. Rohwer
E. M. Rupp
B. L. Whitfield
R. S. Booth
R. J. Raridon

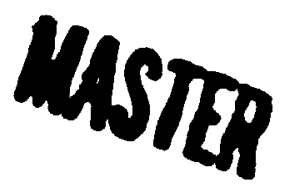

ENVIRONMENTAL SCIENCES DIVISION

Publication No. 1007 



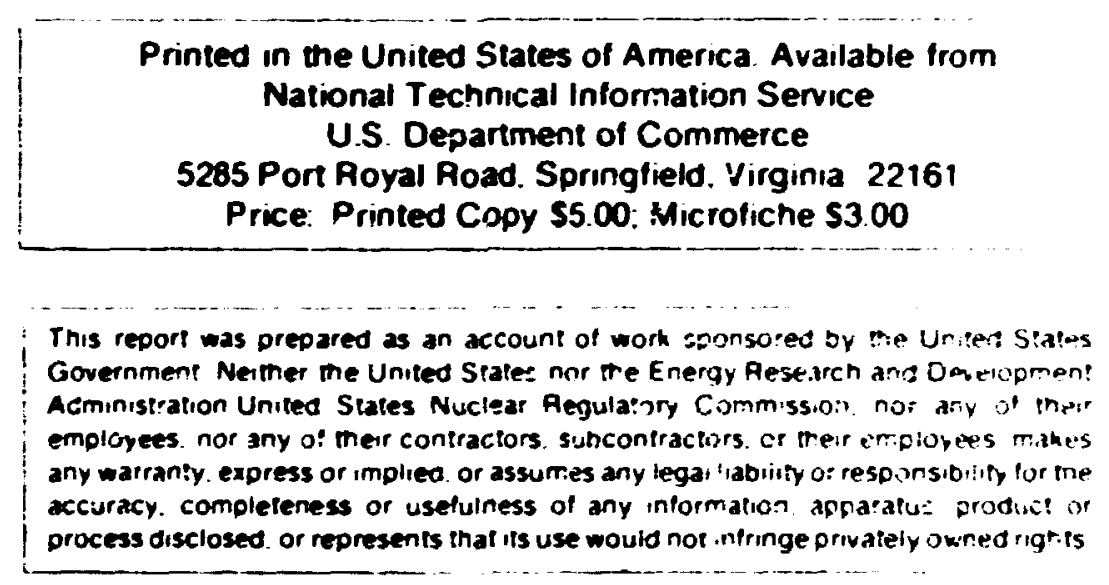



P. J. Walsh
G. G. Killough
D. C. Parzyck
P. S. Rohwer
E. M. Rupp
B. L. Whitfield:
R. S. Booth
R. J. Raridon:

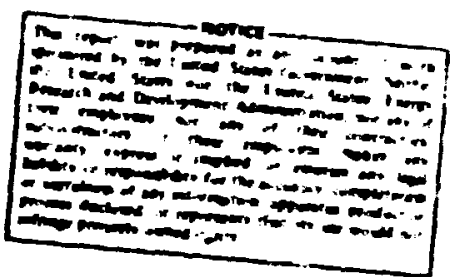

Information Division

Instrumentation and Controls Division

Computer Sciences Division

Date Published: April 197

ENVIRONMENTAL SCIENCES DIVISION

Publication No. 1007
OAK RIDGE NATIONAL LABORATORY
Oak Ridge, Tennessee 37830 operated by UNION CARBIDE CORPORATION
for the

ENERISY RESEARCH ANO OEVELOPMLNT AOMINISTRATION 


\section{ACK:OALEDGASTS}

The authors wish to ackr.ow?edge the helpfil review and cormerts provided by the following rembers of the Enirirenmentai Sciences Jivision Staff: S. I. iwerbach, E. G. Struxness, S. K. Kaye, R. I. Ian Hook. C. $\because$. Miller, C. C. Travis, and C. $\dot{A}$. Little. The authors would especially like to thank E. C. Jones for her important contribution toward completior. of the final report and all previous versions. Also, thanks is due to $\lambda$. L. Lawrence for assistance with early drafts of the report. 
MLLSH, P. J., G. G. KILLOUGH, D. C. PARZYCK, P. S. ROHWER, E. M. RUPP, B. L. MHITFIELD, R. S. BOOTH, and R. J. RARICON. 1977. CunfX - A Cunulative Hazard Index for Assessiag Limiting Exposures to Environmental Poilutants. ORNL-5263. Oak Ridge Kational Laboratory, Oak Ridge, Tennessee. 63 pp.

A hazard index methodology called CunEX has been developed for limiting human exposure to enviromental pollutants. Hazard index is def ined as $Q / Q_{L}$ were $Q$ is exposure or dose to total-body, organ or tissue from all environmental pathways and $Q_{L}$ is a limit wich should not be exceeded because of health risk to humans.

Mathenatical formulations for hazard indices are developed for each sampling medium corresponding to each effluent type. These hazard indices are accumulated into composite indices such that total human intake or dose would not exceed the health risk limit. Mathematical formu?ation for composite hazard indices or CUMEX indices for multiple pollutants are presented.

An example cuntex application to cadmium release from a smelter complex in East Helena. Montara demonstrates details of the methodology for a single pollutant were human intake occurs through inhalation and ingestion. 
TABLE OF CONTENTS

PACEE

LIST OF TABLES ....................... . . ix

LIST OF FIGURES ....................... . . . . . .

LIST OF APPENDICES ...................... . . . . . . . . . . .

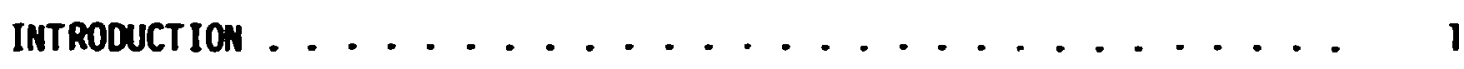

CHAPTER 1. CUMEX FORALLATIOA ............... 2

1.1 Hazard Index .................... 2

1.2 Cuncx Index, Single Pollutant, Multiple Effluent Types, Multiple Pathways ............... 5

1.3 Formulation of a Composite Cuncx Index for Multiple Pollutants.................... 7

1.4 Multiple Pollutants, Different Biological Effects .... 10

1.5 Conclusions ............................ 11

CHAPTER 2. TRANSPORT AND PHYSIOLOGICAL MODELS . . . . . . . II

2.1 Atmospheric Transport Model ............... 12

2.1.1 Input Data ...................... 12

2.1 .2 Examples ................ 13

2.2 Terrestrial Transport ................ 13

2.2.1 Input Data ............... 15

2.2 .2 Output Data ................. 16

2.3 Aquatic Transport ................. 16

2.4 Phystological Models ................. 16

2.5 Selection of Limits ................ . . 17

CHAPTER 3. JUSTIFICATIONS FOR EXAMPLE CUMEX APPLICATION . . . . 18

3.1 Selection of Cadniur. ................ 18

3.2 Selection of Endpoint .............. 18 


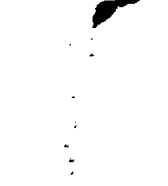$$
\text { : }
$$ 
TABLE Of CONTENTS (conti ed)

PAGE

3.3 Selection of Helena Smelter Complex ......... 19

3.4 Environmental Concentrations of Cadmium ....... 19

3.5 standards .......................... 21

CHAPTER 4. CUMEX APPLICATIJW ............. 21

4.1 Atmospheric Transpo. 'Hodel ........... 21

4.1.1 Input Data ................... 21

4.1 .2 output Data .................... 22

4.1.3 Comparison with Measurements ........ 23

4.2 Terrestrial Transport Model ............ 31

4.2 .1 Input Data ................ 32

4.2 .2 Output Data ................... 33

4.2.3 Comparison with Measurements ........ 34

4.3 Calculation of CUmEx Index . . . . . . . . . 34

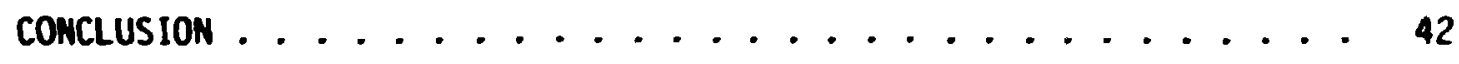

APPEMDIX !. MODIFICATIONS OF TERMOD ........... 43

APPENDIX II. CRDMIUM REVIEW ............... 47

REFERENCES ............................ 59 
3.4.1 Average cadnicm concentrations ............ 19

3.4.2 The average daily intake of cadmium as a function of diet for the U.S. and the Study site in Helena, Montana.... 20

4.1.1.1 Source data for East Helena snelter area ........ 22

4.1.2.1 Deposition of cadmiun around Helena smelter area . . . . 24

4.1.2.2 Air concentrations of cadmiun around Helena smelter area...................... 25

4.1.2.3 Deposition of cadmium around Helena smelter area . . . . 30

4.1.3.1 Cadmium concentrations in area around East Helena .... 31

4.2.2.1 Equilibriun cadmiun concentrations in various

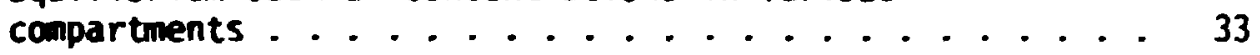

4.2.2.2 Equilibrium intakes by reference man .......... is 
LIST OF FIGURES

FIGURE

PAGt

2.2.1 Block diagram of the terrestrial food pathways ...... 14

4.1.2.1 Average deposjtion of cadmium $\left(5_{-}\right)$around East Helena smelter $\left(\mathrm{mg} / \mathrm{m}^{2} /\right.$ month $) \ldots \ldots 26$

4.1.2.2 Average air concentration of cadnium (5:) around East

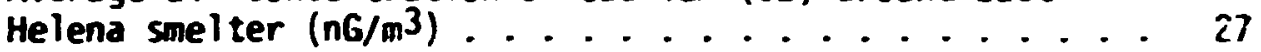

4.1.2.3 Air concentration of cadmium around East Helena smelter area as a function of particle size and distance .... 28

4.1.2.4 Deposition of cadnium around East Helena smelter as a function of particle size and distance........ 29

4.2.3.1 Intake rate of cadniun vs time after an impulse, ground deposition of $15 \mathrm{jg} / \mathrm{m}^{2}$. Intake is by reference man 43 whose diet consists of 250 dry grams of vegetables/day, $1.02 \mathrm{mi} ! \mathrm{k} /$ day, 300 wet grams of beef/day and a total, solid food intake (less fish, beef, and vegetables) of 2500 wet grams/day. The half-time for loss of cadmium from the subsurface soil pool and pasture soil was 10

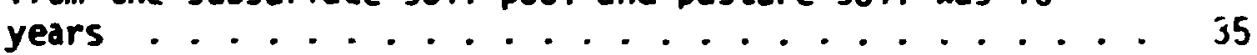

4.2.3.2 Intake rate of cadmium vs time after an impulse, grnygd deposition of $15 \mathrm{wg} / \mathrm{m}^{2}$. Intake is by reference man. The half-time for loss of cadmium from the subsurface soil pool and pasture soil was 50 years ........ 36

4.2.3.3 Percent of daily cadmium intake from each pathway as a function of time after an impulse, ground deposition of $15 \mu \mathrm{g} / \mathrm{m}^{2}$. Intake is for reference man. 43 The half-time for loss of cad ium from the subsurface soil pool and pasture soil was 10 years. See Fig. 4.2.3.1 for intake rates in $\mu g /$ day .................

4.2.3.4 Percent of daily cadmium intake from each pathway as a function oi time after an impulse, ground deposition of $15 \mu \mathrm{g} / \mathrm{m}^{2}$. Intake is for reference man. 43 The half-time for loss of cadnium from the subsurface soil pool and pasture soil was 50 years. See Fig. 4.2.3.2 for intake rates in $\mu g /$ day ................ 


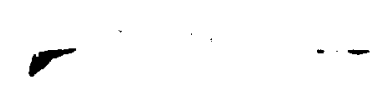

$\cdots+\cdots$

BLANK PAGE

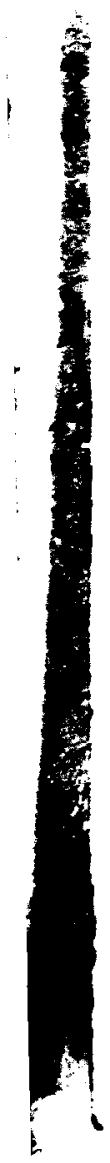


LIST OF FIGURES (continued)

FIGURE

PAGE

4.2.3.5 Percent of the totil, ic-y:ar intake of cadnium through each pathway up to lige $c$ after an impulse, ground deposition of $15 \mathrm{\mu g} / \mathrm{m}^{2}$. Also, multiplication by 1.05 converts these plots to the intake rate ( $\mathrm{g} / \mathrm{day}$ ) of cadmium as a function of time after a constant deposition sourcf of $15 \mathrm{~kg} / \mathrm{m}^{2}$-day first appears. Inputs are for reference man. 43 The half-time for loss of cadniun: from the subsurface soil pool and pasture soil was 10 years ......................

4.2.3.6 Percent of the total, 50-year intake of cadiniun through each pathway up to tine $t$ after an impulse, ground deposition of $15 \mathrm{\mu g} / \mathrm{m}^{2}$. Also, multiplication by 2.12 converts these to the intake rate (ug/day) of cadmium as a funçtion of time after a constant deposition source of $15 \mu \mathrm{g} / \mathrm{m}^{2}$-day first appears. Inputs are for reference man. 43 The halftime for loss of cadnium from the subsurface soil pool and pasture soil was 50 years ............ 


\section{LIST OF APPENDICES}

\section{APPEMDIX}

PAGE

I Modificatians of TERTMO .............. 43

II Cadniun Review ................... 47 


\section{INTROOUCTION}

This report describes a hazard assessment methodolugy for limiting human exposures to envirormental pollutants such that exposure or dose will not exceed some preselected value. An estiation of total pollutant intake by mumans and resulting neal th effects must include contributions from all possible routes of exposure. Models must be used for estimation of potential health impacts of pollutant releases that have not yet occurred. They are also useful when measurements can be made. Therefore, an assessment approach has been developed using environmental transport models to predict transport from point of pollutant release or measurement to eventual intake and absorption by huans.

This assessient methodology called curEX (cumlative hazard index) is based on consideration of interrelationships between environmental compartmenis. A measurewent in a particular sampling medium, for example, is sufficient to calculate total huan intake via all routes of exposure from that sampling mediun, within limits imposed by model input data. The CunEX assessment methodology in part extends an existing radiological assessment technology (CUEX) to the nonradioactive area. 1,2 Although the assessment problens are similar, some features of radioactive releases have faciiitated assessment of their environmental impact. Radioactive releases have been relatively small and subject to strict controls. Possible health hazards of radiation were recognized early, thus research on biologica! effects and transport of radionuclides through the food chain has been underway for many years. The pharmacological action of radionuclides has not been considered. If only radiacion effects are considered, a comion unit, the rem, is used to sum effects of several different radionuclides. No comparable index of effect exists for nonradioactive pollutants. This latter point is particularly critical in nonradioactive pollution assessment because simultaneous exposure to several pollutants may result in synergistic or antagonistic effects rather than simple additive effects. Experimental data are essential to assess these effects and are not available for most combinations of pollutants. Therefore, at present, the cumEX methodology is strictly applicable to single pollutants only. The CUnEX 
methodology provides a way to organize and ise data obtained from experimental and theoretical studies. In its initial stages, the methodology is purposefully kept as sieple as possible wile still considering multiple pollutants and multiple environmental pathays.

Transport models used in CunEX appl ication estimate pollutant dispersion through air and wter, deposition on soil and plant surfaces, uptake by plants, concentrations in air and water, intake by animals and huan exposure through inhalation and ingestion. Physiological wodels estiate pollutant uptake and subsequent distribution anong organs. Models used at the 0a: Ridge Kational Laboratory for CUnEX application are described in Chapter 2.

The overall curcx conceft, wich ties together pollutant emission, environmenial transport, and 1 human health effect endpoint (for example a statutory liait or standare, organ level, total-body burden, or specific disease state), provides a useful method to assess compliance with existing standards; to suggest standards where none exist; to estimate health effects of a given pollutant release; or to estimate the anount of pollutant released based on concentrations found in a sampling medium.

The major feature of CUnEX is a calculated CunEX index wich relates the concentration of a pollutant in air or other sampling medium to a preselected endpoint such as an organ concentration by consideration of all pathways from point of measurement to endpoint. Derivation of the formulation required for this calculation is presented in Chapter 1 and Chapter 3 discusses selection of cadiuium as an important environmental pollutant.

Chapter 4 illustrates application of the CUnEX methodology to cadnium release from the smelter complex in East Helena, Montana.

\section{CHAPTER 1. CUNEX FORIULATION}

\section{I Hazard Index}

A hazard index (H.I.) is a quotient of exposure or dose of a given environmental pollutant with some "accepted" or "selected" limit. Its application is implied in any case where actual or estimated exposure or 
dose to total-body, organ or tissue is compared to a recommended limit for a particular agent. The President's Science Advisory Commitiee on Chemicals and tealth ${ }^{3}$ recomnends that some index of probability of human exposure be used co rank chemicals in the environment. It is suggested that physical, chenical and economic information along with information on biological effects wight be combined into an aggregate index of hazard. However, estimation of hazard index when a straightforward measurement or calculation does not apply is neither simple nor widely accomplished. When exposure of humans to multiple environmental pollutants via mutiple environmental pathways is of concern, complexitie and lack of information sometines render determination of hazard indices very crude at best. Still the concept is very useful in a general way because it provides a convenient and perhaps meaningful comparison between exposure or dose levels on the one hand and limits based on biological effects on the other.

The hazard index may be defined mathematically as,

$$
\text { H.I. = Q/Q },
$$

where $Q$ is exposure, or dose to total-body, organ or tissue from all environmental pathways and $Q_{L}$ is a selected or established limit which should not be exceeded because of health risk to man. The determination of $Q$ may include metabolic or physiological models to connect totalbody, organ or tissue burden to envirommental levels if $Q_{L}$ is available in these terms.

Fortunately, exposure modes resulting in intake by man are limited. They are inhalation, ingestion, transpiration or entry through a break or wound. Thus with $Q$ defined as organ burden, we may write

$$
Q=Q_{H}+Q_{G}+Q_{T}+Q_{H}
$$

where $Q_{H}, Q_{G}, Q_{T}$, and $Q_{H}$ represent components due to inhalation, ingestion, transpiration, and entry through a wound, respectively. We may 
further express these quantities in terms of environmental concentrations affecting then as follows:

$$
\begin{aligned}
& Q_{H}=C_{A} V_{A} f_{d} \tilde{R}(-g), \\
& \tilde{R}=\int_{0}^{T} R(t) d t,
\end{aligned}
$$

where

$C_{A}=$ pollutant concentration in air $\left(\mathrm{wg} / \mathrm{cm}^{3}\right)$,

$V_{A}=$ breathing rate of reference individual (ca/day),

$f_{A}=$ fraction of inhaled pollutant deposited in reference organ,

$\hat{\bar{R}}=$ cumulative retention to tine $T$ of pollutant in reference organ (days), and

$R(t)=$ time dependence of fractional retention of pollutant in reference organ.

$$
Q_{G}=\left(c_{F} n_{F}+c_{W} v_{W}\right) f_{w} \tilde{R} \quad(j g) .
$$

where

$C_{F}=$ average concentration of pollutant in food $(\mu \mathrm{g} / \mathrm{g})$,

$M_{F}=$ mass consumption rate of food $(g /$ day $)$,

$C_{W}=$ average concentration of pollutant in drinking water (ug/al),

$V_{W}=$ volune consuaption rate of drinking water (al/day), and

$f_{w}=$ fraction of ingested pollutant reaching reference organ.

$$
Q_{T}=C_{A} K f_{b} \tilde{R}(L g) .
$$

where

$C_{A}=$ concentration of pollutant in air $\left(\mu \mathrm{g} / \mathrm{cm}^{3}\right)$,

$K=$ partition coefficient for pollutant between air and blood $\left(\mu \mathrm{g} / \mathrm{ml} \mathrm{per} \mu \mathrm{g} / \mathrm{cm}^{3}\right)$, and 
$f_{b}=$ fraction of pollutant in blood that is deposited in the reference organ.

Intake due to entry through break or wound is not generally quantifiable and must be analyzed for each specific instance. Fortunately, this intake route is not usually significant compared to the major routes of inhalation and ingestion.

Aditional factors or fewer factors could be included in the above equations depending on whether $Q$ applies to tissue, organ or total-body concentrations.

\subsection{Cuncx Index, Single Pollutant, Multiple Effluent Types, Multiple Pathways}

Determination of $C_{A}, C_{F}$ and $C_{W}$ defined in Section 1.1 requires an environmental assessinent or human exposure assessment. If the relationships among the various environmental compartnents are understood, then measurements in a particular sampling mediun (air, water, food) can suffice, along with transport models, to assess human intake. Measurements in at least two sampling media, along with transport models, will be necessary to assess total human intake if there is more than one effluent type. For example, suppose we wish to determine an air concentration, $C_{A}$, such that an organ burden $Q$ from all pathays and all routes of entry is equal to an accepted organ burden limit $Q_{1}$. In such a case we set $Q=Q_{L}$ and solve for $C_{A}$, thus:

$c_{A}=\frac{Q_{L}}{\left[v_{A} f_{a}+\left(c_{F} / C_{A}\right) n_{F} f_{W}+\left(C_{W} / C_{A}\right) v_{W} f_{W}+k f_{b}\right] \tilde{R}}$.

Equation (1.2.1) obviously requires relationships among $C_{A}, C_{F}$, and $C_{H}$. The ratio $\left(C_{F} / C_{A}\right)$ is not simply the transfer coefficient from air to food since the concentration in food results from other pathways as well. Similarly $\left(C_{W} / C_{A}\right)$ is not simply the transfer coefficient from air to water. Calculation of $C_{A}$ by $E q$. $(1.2 .1)$ requires that $C_{A}, C_{F}$ and $C_{W}$ 
be determined separately. However, thare is a simpler approach wich yields to wore direct analysis.

A hazard index may be deternined for each sampling mediun corresponding to each effluent type. Hazard indices ay then be accumlated into a composite hazard index. From these hazard indices one way determine an exposure such that total hman intake or cose is equal to some preselected value. We call such a cumlative exposure index a curkx index. If only one sampling mediu contributes to hum miake then the curkx index is determined such that intake via all environmental pathways from that sapling medium is equal to some preselected value. Thus the CurEX index, $C_{A}$, for an airborne effluent with air as the sampling nedica is,

$$
c_{A}^{*}=\frac{Q_{L}}{\left(v_{A} f_{a}+\right.} \frac{\left.f_{A F} M_{F} f_{W}+f_{A M} v_{W} f_{W}+k f_{b}\right) \widetilde{R}}{.}
$$

where

$f_{A F}=$ transfer coefficient from air to food, and

$f_{A W}=$ transfer coefficient from air to water.

Both $f_{A F}$ and $f_{A H}$ are determined by environmental transport models. The cuncx index for a liquid effluent with water as the sampling medium is,

$$
C_{W}^{\star}=\frac{Q_{L}}{\left(f_{W F} M_{F} f_{W}+v_{W} f_{W}\right) \tilde{R}} \text {, }
$$

where $f_{M F}=$ transfer coefficient from water to food. When both effluent types are present, joint $l$ inits on $C_{A}$ and $C_{W}$ are set by the relation,

$$
\frac{C_{A}}{C_{A}^{\hbar}}+\frac{C_{H}}{C_{H}^{\hbar}} \therefore 1
$$


The inequalities, Eq. $(1.2 .4)$, and $C_{A}>0, c_{W}>0$ correspond to the shaded region in the diagram below. The analysis could, of course, be extended to higher dizensions.

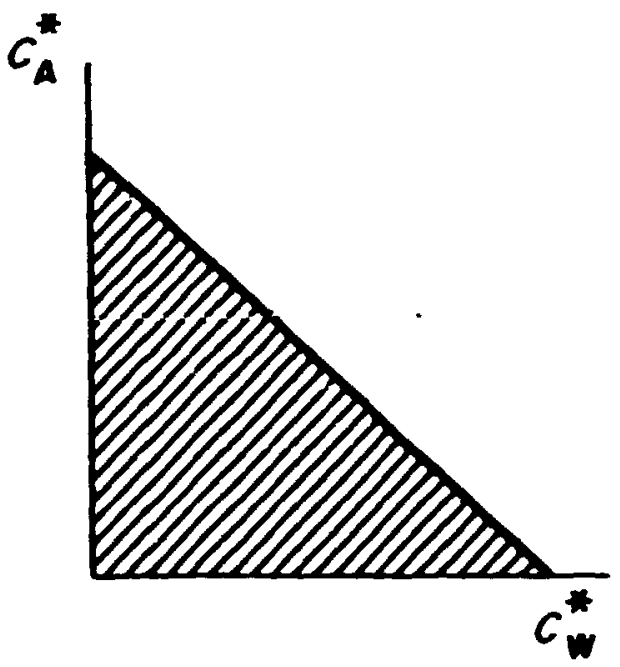

The above discussion illustrates the major features of the CUnEX concept for a single pollutant. As environiental transport models evolve for determination of $f_{A F}, f_{A M}, f_{M F}$, etc., so will the CunkX concept. As more camplicated kinetic processes are incorporated into the models, such as photochenical, chemical or biological alterations of pollutants, determination of Cumitindices will become more precise.

\subsection{Formulation of a composite CUmEx Index for Multiple Pollutants}

We consider measures of exposure $Q_{1}, Q_{2}$ to two pollutants, such as burdens in an organ. Associated with the presence of either or both is a discernible effect which can be used to quantify imits.

We conceive of a serfes of experiwents in wich various combinations of the two toxicants are introduced into the tissues at risk. For a given level of $Q_{1}$, wagine an increase in $Q_{2}$ until the 1 imiting 
effect is observed, and the process is repeated for other levels of $Q_{1}$. The results might be visualized as in the diagran below:

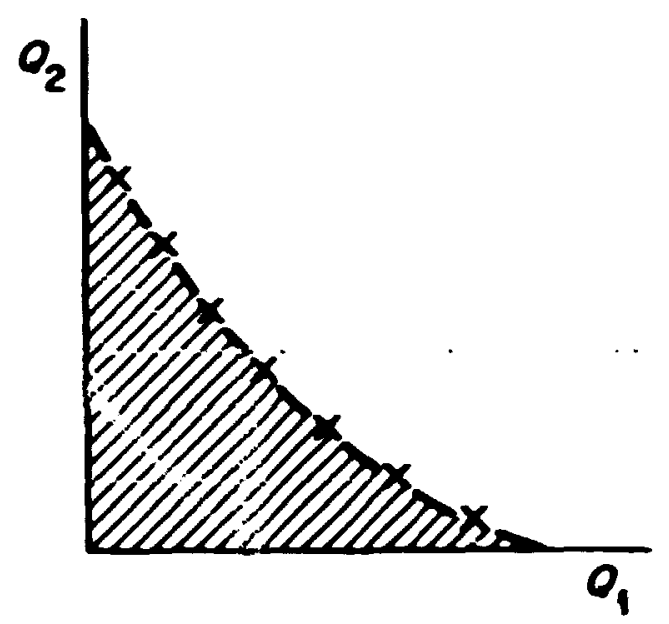

where the plotted $x$ 's represent the attainment of the limiting effect.

A model for the 1 imiting curve on wich $x$ 's lie might be hypothesized as

$$
F\left(Q_{1}, Q_{2}\right)=A_{1} Q_{1}+A_{2} Q_{2}+K_{12} Q_{1} Q_{2}=1 \text { (conic section). }
$$

Our problem may be viewed as that of estimati.ıg the parameters $A_{1}, A_{2}$, and $k_{12}$ in order that we might control the biological availability of the pollutants in such a way as to keep

$$
F\left(a_{1}, a_{2}\right)<1
$$

The coefficients have the following interpretations:

$A_{1}^{-1}=$ limiting burden of $Q_{1}$ in the absence of $Q_{2}$,
$A_{2}^{-1}=$ limiting burden of $Q_{2}$ in the absence of $Q_{1}$, 
$k_{12}=$ interaction term wich characterizes the synergistic effect of both agents:

$K_{12} \cdot 0$ impl ies reinforrenent,

$K_{12}<n$ inplies interference, and

$K_{12}=0$ iaplies no interaction.

These interpretations may be visualized as follows:

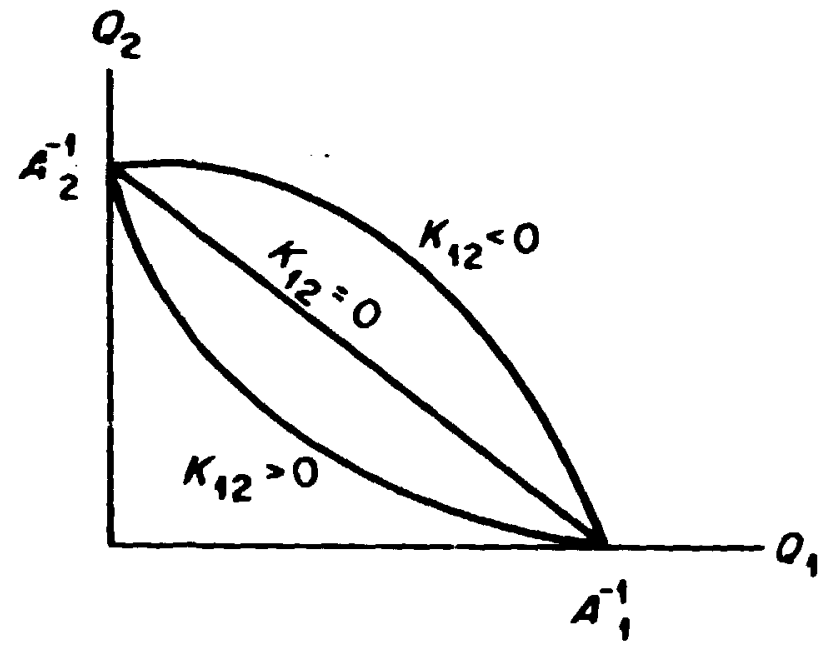

The inequalities $f\left(Q_{1}, Q_{2}\right)<1, Q_{1} \geq 0, \eta_{2} \geq 0$ correspond to the shaded region under the curve limited below and to the left by the coordinate axes:

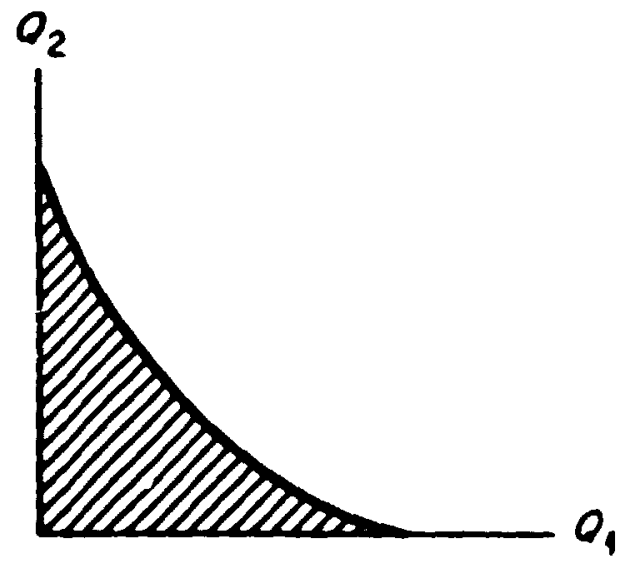


Generalization of the formblation to higher dimensions is straightforward:

$$
F\left(Q_{1}, \ldots, Q_{n}\right)=\sum_{i=1}^{N} A_{i} Q_{i}+\sum_{j=1}^{N} \sum_{i=1}^{j-1} k_{i j} a_{i} a_{j}
$$

+ higher-order interaction terms.

In general, however, it is doubtful that sufficient experimental information could be generated for estimation of higher-order interaccion coefficients.

To illustrate the application, consifer environmental levels of pollutants 1 and 2 , with air concentrations $C_{A, 1}, C_{A, 2}$. The equation for one pollutant is Eq. $(1.2 .2)$. The limit for two pollutants is reached whenever

$F\left(Q_{1}, Q_{2}\right)=A_{1} E_{1} C_{A, 1}+A_{2} E_{2} C_{A, 2}+K_{12} E_{i} E_{2} C_{A, 1} C_{A, 2}=1$,

where

$E_{j}=\left(v_{A} f_{a, j}+f_{A F, j} M_{F} f_{W, j}+f_{A, H, j} v_{W} f_{W, j}+K_{j} f_{b, j}\right) \tilde{R}_{j}$.

Thus a critical air concentration pair $\left(C_{A, 1}, C_{A, 2}\right)$ lies on the curve whose equation is Eq. (1.3.4). This curve takes synergism into account in the third term.

The above analysis applies for multiple pollutants in one sampling medium for one effluent type. The application may be extensed to incorporate multiple effluent types and multiple sampling media in a manner similar to that given in Section 1.2 .

\subsection{Multiple Pollutants, Jifferent Biological Effects}

The discussion of multiple pollutant effects given in Sectior 1.3 applies strictly only if the multiple pollutants affect the same target 


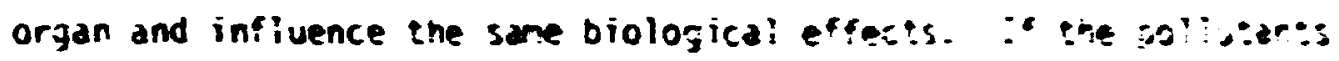
affect different organs or produce different biciogicai ecsec:s ir :as sane or differsent organs, then other considerations will mive $:=$ : included in the rodel. For example, eact pollinin: -ay hase :s te wighted according to its influence or the 0 sal well seing, she organise:. Research along such lines shoulo eventuail; lead :0 a $\mathrm{cx}$ prehensive approach for determination of curviative hazard indices $\mathrm{gr}$ cuntex indices.

\subsection{Conclusions}

It is conceptually feasible to deterrine -ulinedia, -uitisz:hwy and multipollutant cualative hazard indices such that control of $x$ lixtant concentrations in one or two sampling redia correspondiar so whe:her there is one or more effluent types will assure that total hran ireste will not exceed some preselected value. Such surulative hazard indices determined as 1 initing exposures are called CURX indices. A CSMEX index is site specific in terms of enission sources and sarolieg redia but there is no conceptual barrier to determination of Grikx indices for multiple sources as well as multiple pathmays to the sappling rediur.

Cincx indices conceptually provide an irterface between huran exposure assessents and huan health risk assessasent. Their practical determination, however, requires detailed knowledge of source mission characteristics, environiental transport processes and biological effects. Tinus the Curkx concept provides a framework to assirilate such knowledge and to point out where more research is needed. Its applications will be more definitive as information develops; however, it is certain that such concepts will huve to be applied conservatively before all desired information is available.

CHAPTER 2. TRAMSPORT MO PHYSIOLOGICAL MOOELS

A brief description of models used in present application of cumex methodology at Oak Ridge Mational Laboratory (ORYL) follows. 


\subsection{Atmospheric Iransport Model}

The Atmospheric iransport Madel (ATM) is based on a Gaussian plume model and is capable of calculating wet and dry deposition and air concentration oí gaseous and particulate pollutants at various receptor points located within $50 \mathrm{~km}$ of a source or sources. ${ }^{4,5}$ The ATM can treat point, area, and line sources, including wind blowr. sources. As the plume from each source travels downwind ( $x$-direction) it spreads out ( $y$ - and z-directions). The user can specify computation of the amount of such spreading from either Pasquill-Gifford or Briggs-Smith dispersion parameters. The plume is depleted by both dry and wet removal. Dry removal involves fallout and deposition. The dry fall depositicn mechanism employs a deposition and terminal velocity concept sucn that the net flux of material is from plume to landscape surface at a rate proportional to the atmospheric concentration in the layer adjacent to the ground surface. Gases such as $\mathrm{SO}_{2}$ will deposit on a surface even though they have no terminal velocity. For particulate emissions, the plume is assumed to "tilt" downward at an angle determined by the terminal velocity of the particle in question. For gases, the plume does not tilt.

\section{1 .1 Input Data}

Input data required to apply ATM to a given area are as follows:

(1) Source characteristics. Sources of pollutants may be points such as smoke stacks; lines, such as roads; or areas, such as cities or industrial complexes. There is also provision for including a wind blown source such as a pile of mine tailings. For each source location it is necessary to specify rate of pollutant output, height at which the poilutant is being emitted, and for stack release, plume rise parameters, which are related to effluent velocity and temperature.

(2) Pollutant characteristics. For gases the boundary layer thickness and diffusion constant for washout are required. For particulates the density and diameter or particle size distribution must be spe:ified. Chemical properties for both gases and particulates should be specified. 
(3) Receptor characteristics. Location of receptor points relative to the sources must be given. Also, type of cover (grassland or forest) and surface roughness must be specified.

(4) Meteorological conditions. The wind rose for the source region is required as a function of time period wich may be an hour, day, sonth. season or year. The windiose is built into the model as a frequency table, wich describes as a fraction of time the occurrence of a particular combination of stability class type, wind direction, and wind speed class. Frequency and intens:ty of rainfall is also required and in some cases it may be necessary to differentiate between daylight and night conditions.

\subsubsection{Examples}

The ATM has been applied to the area around Oak Ridge, Tennessee, to estimate the impact of effluents from coal-fired steam plants on the environment. Correlation of sulfur dioxide measurements at several gages with ATM predictions was good $(r=0.80) .^{6}$ Application of the ATM on Walker Branch Hatershed illustrated close agreement between measured and computed depositions of particulates. 7 For example, for $\mathrm{Cr}, \mathrm{Mn}$, and Ni. maximum computed depositions were 7, 30, and $10 \mathrm{~g} / \mathrm{ha}$-month, respectively, wile corresponding ranges of measured input were: $\mathrm{Cr}(0.5-11)$, Mn (4-58), and $\mathrm{Ni}(1-20)$.

If source strength and input data are known, deposition and air concentration at a given location can be computed. Conversely, if a maximum limit of deposition or air concentration is specified, ATM can be used to compute maximum allowable pollutant output from a given source.

\subsection{Terrestrial Transport}

Output from the ATM in terms of $\mu \mathrm{g} / \mathrm{m}^{2}$-day of the pollutant deposited on the ground at a given distance fron the pollutant source can serve as input to TERMOD. ${ }^{1,2}$ Terrestrial transport pathways considered by TERMOD are shown in Fig. 2.2.1. 
OANL- OWJ 7O-11?334A3

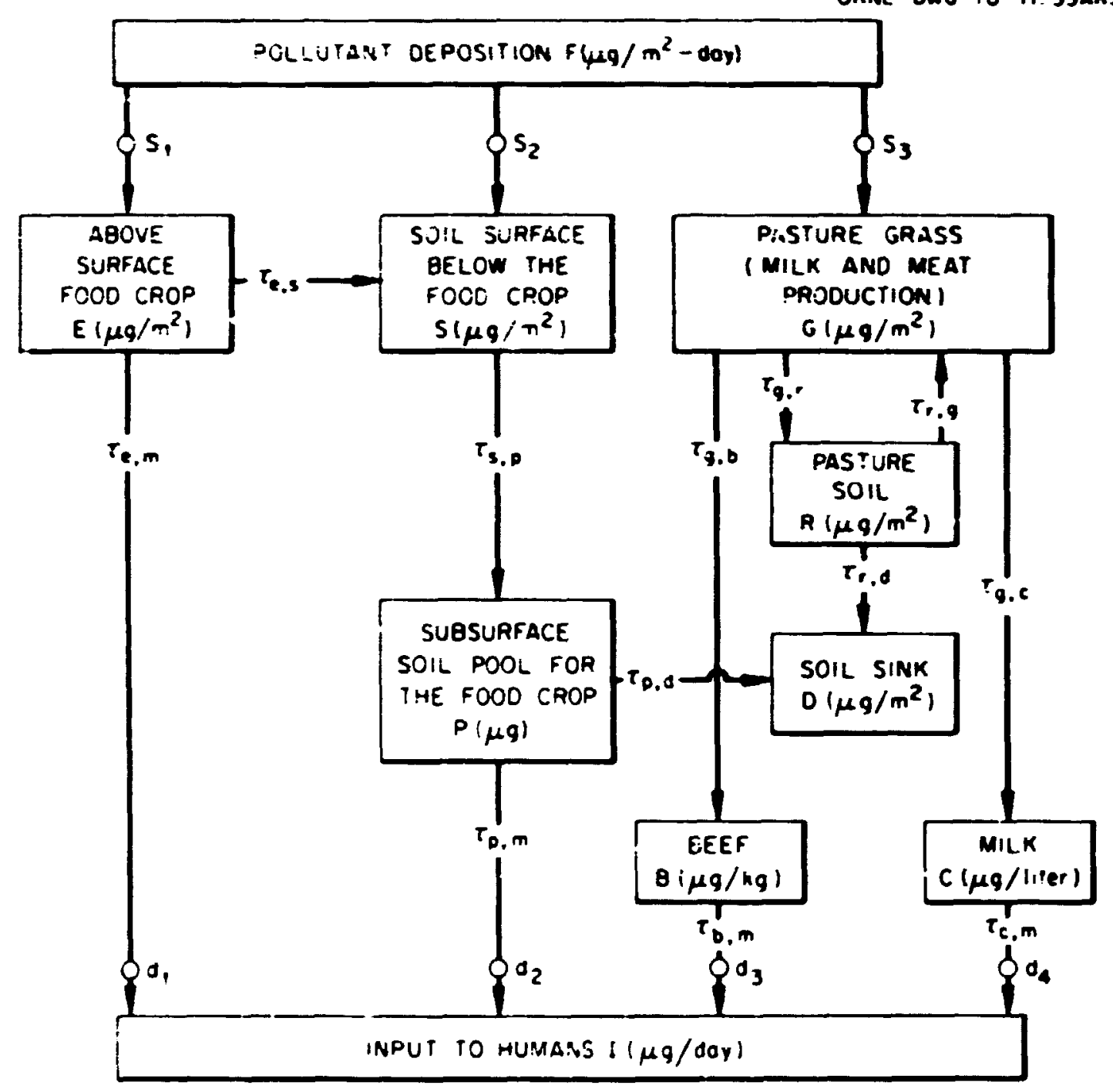

Fig. 2.2.1. Block diagram of the terrestrial food pathways. 
In gemeral, build-up of pollutants in food chains and their flow and distribution in the environment can be divided into a series of compartments. Distribution in soil will depend upon air concentrations and hydrologic redistribution as well as tilling of soil and action of earthorms, erosion, resuspension, rainfall, types of vegetation present, soil type, pH, and wind action. ${ }^{8,9,10}$

Since a swelter or power plant may be considered a point source, there is an inverse relationship between concentration at the source and distance from the source. In plants, as in soil, there is a correlation between distance from the pollutant source and pollutant concentrations in vegetables and grasses. 7 There is also a positive correlation between soil concentration and levels in plants. $11,12,13$

\subsubsection{Input Data}

Application of TEROWO is illustrated in Fig. 2.2.1. Pollutant deposition is the only source compartiment and man is the only receptor compartiment of interest. Detailed discussions of TERMOD parameters are given in Refs. 2 and 21.

Three transfer coefficients are usually considered a function of the element being modeled. These are:

(1) ${ }^{\top} g, b$, transfer coefficient from grass to beef,

(2) ${ }^{\top} g, c$, transfer coefficient from grass to cow (milk),

(3) $\tau_{p, m}$, transfer coefficient from subsurface scil pool for the food crop to man.

A single value or set of values are usually selected for the remaining transfer coefficients. They are selected with the objectives that the model be realistically conservative, the dependent variables simulate a realistic dynamic behavior and the biomass and pollutant mass be conserved. $^{2}$ Application of TERMOD in CUmEX application to cadmium is described in Chapter 4. Modifications cf TERAmO necessary for CUMEX application to cadmium are given in Appendix 1 . 


\subsubsection{Output Data}

Outputs of TERrDD, as illustrated in Fig. 2.2.1, are intakes of pollutants by man through consuption of milk, beef and plant parts contaninated directly by deposited pollutants as well as by uptake from soil.

Pollutant corcentrations in soil, plants and animals as calculated by the transport model as mell as model predictions of dietary intake by humans can be compared to experimentally determined values. Predictions can be made of environsental responses to changes in pollutant emission levels.

\subsection{Aquatic Transport}

Aquatic transport models can be used to estimate pollutant flow through the aquatic food chain. In the Environmental Sciences Division at ORNL AQUAMOD 14 is the aquatic transport model. AQUAMOD is an aquatic ecosystem model and was originally intended for predicting dose to man from a radioactively contaminated aquatic environment. Modifications to AQUAMOD are being made in order to have the capability of predicting aquatic food chain transport of nonradioactive pollutants. A specific activity approach is used for both radioactive and nonradioactive pollutants. In the near future AQUANOD will have the capability of calculating time dependent bioaccumulation factors. These will be useful in assessment work when empirically determined time dependent bioaccumulation factors are unavailable for accidental releases of pollutants into an aquatic environment.

\subsection{Physiological Models}

Physiological models ur. $f$ in CUMEX application vary with properties of the pollutant being considered. For the assessment of cadmium release presented in Chapter 4 the model discussed by Friberg et al. was 
used. 9,13 The rodel computes total-body burden $B(t)(. .9)$ at time $t$ as follows:

$$
B(t)=\underline{\operatorname{lf}\left(1-e^{-i t}\right)} .
$$

where $I=$ intake rate $(: g /$ day $)$ for the particular exposure mode (ingestion or inhalation).

$f$ = fractional absorption for the particular exposure mode, and

$l=$ fractional daily excretion rate.

\subsection{Selection of Limits}

Selection of the exposure, dose or concentration limit $Q_{L}$ depends upon knowledge of biological effects of the particular environmental pollutants of concern. Sometines such iniormation is readily available as exposure or dose limits but in other cases $Q_{L}$ will require a fully documented derivation. It is imperative that the method of determination of $Q_{L}$ be clearly specified in each application.

Selection of kidney cortex as the critical tissue for cadmium is discussed in Chapter 3; however, to enable the physiological model to calculate cadmiun concentration in kidney cortex as the critical tissue the following formula must be included:

$$
C(t)=\frac{1}{3}(1.5) \frac{B(t)}{m} \text {, }
$$

where

$C(t)=$ concentration in kidney cortex $(: 1 g / g)$,

$\frac{1}{3}=$ fraction of total-body burden $B(t)$ found in kidneys,

$m=$ mass of kidneys $(300 \mathrm{~g})$, and

1.5 = increase in cadniun concentration of kidney cortex over that of kidney as a whole. 


\section{CHATTER 3. JUSTIFICATIOAS FOR EXMPLE CUNEX APPLICATION}

\section{3. i Selection of Cadmiva}

Cadaiva is a toxic heavy metal widely used in a variety of consumer products. It produces acute health effects wen inhaled or ingested at high concentration and chronic effects at lr.wer concentrations. As an ubiquitous element in the environment, it is found in normal diet and in air in most urban areas. It is excreied from the body extremely slowly, accumlating to potentially toxic levels men intake is sufficient. As an environmental pollutant of increasing importance due to increasing comercial use and fossil fuel combustion and as a pollutant about wich health effects data are available, cadaiu is well suited for testing the Cunix methodology. (See Refs. 7 and 9 and Appendix II for more detailed discussion.)

\subsection{Selection of Endpoint}

The endpoint chosen for calculation of a cincx index for cadaium release is $200 \mathrm{~g} \mathrm{~g} \mathrm{~L} / \mathrm{g}$ wet weight of kidney cortex $:$ i.e. $Q_{L}=200 \mathrm{hg} / \mathrm{g}$ ). From epidemiological and experimental studies kidneys are the long-term target organ for low-level exposure to cadmium. 9 A concentration of 200 . g Cd/g wet weight of kidney cortex is generally accepted as a level atove which kidney damage occurs. ${ }^{9}$ At constant exposure levels the increase in kidney cadinium concentration is almost linear through age $\mathbf{5 0}$ years. The CumEx index calculations in this report are intended to prevent accumulation above $200 \mathrm{wg} \mathrm{Cd} / \mathrm{g}$ wet weight kidney cortex in 50 years, assuming a total kidney weight of $300 \mathrm{~g}$ and a fractional absorption of 0.05 for ingestion and 0.25 for inhalation. 7,9 Excretion is assumed to te 0.005\% of total body burden per day. (See Refs. 7 and 9 and Appeisid II for more detail.) 


\subsection{Selection of Helena Smelter Complex}

CuncX is a site specific assessment methodology; therefore, a site of cadaiu release was selected were source data and other input data for transport models were available. A study by the U.S. Environmental Protection Agency (EPA), conducted between June 1969 and June 1970 provided the required data for an area around East Helena, Montana, site of a lead swelter and slag processing facility. ${ }^{8}$ Cadaium is one of the major pollutants released from this snelter complex.

\subsection{Enviromental Concentrations of Cadmium}

Average cadmium concentrations in air and water for the United States as a mole and for the Helena Valley and East Helena are given in Table 3.4.1.

Table 3.4.1. Average cadnium consentrations

\begin{tabular}{|c|c|c|c|}
\hline Sample Mediun & U.S. & Helena Valley 8 & East Helena \\
\hline Air $\left(\mu g \mathrm{Cd} / \mathrm{m}^{3}\right)$ & $\begin{array}{l}0.02 \text { urban } \\
0.003 \text { nonurban }\end{array}$ & 0.03 & $0.06-0.25$ \\
\hline Water (ug $\mathrm{Cd} / \mathrm{l}$ ) & $<10$ & $<10$ & .10 \\
\hline
\end{tabular}

Average Cd concentrations in foods are quite variable but usually less than $0.05 \mathrm{ug} \mathrm{Cd} / \mathrm{g}$ wet we ight. 7

Table 3.4.2 shows cadmium concentrations in items of selected food categories given on a wet weight $(\mu \mathrm{g} / \mathrm{g})$ basis. The cadmium concentration values have been taken from a number of different source documents and these references are given in Table 3.4.2. Table 3.4.2 also gives the daily intake of cadmium for each of the major food categories with the daily cadmium intake value for all categories given at the bottom of the table.

Dafly intake values given in Table 3.4 .2 are based on a daily food intake of $1.75 \mathrm{~kg}$ as compiled by the U.S. Department of Agriculture ${ }^{15}$ 
Table 3.4.2. The average daily intake of cadmium as a function of diet for the U.S.

and the study site in Helena, Montana

\begin{tabular}{|c|c|c|c|c|c|c|}
\hline Food category & $\begin{array}{c}\text { Consumption } \\
\text { g/day - } \\
\text { edtble portions }\end{array}$ & $\begin{array}{l}\begin{array}{c}\text { Cadmium } \\
\text { concentration }\end{array} \\
\frac{\text { Range }}{\mu g / g \text { wet } \mathrm{wt}^{\mathrm{a}}}\end{array}$ & $\begin{array}{l}\text { Avera } \\
\text { U.S. }\end{array}$ & $\begin{array}{l}\text { Intake } \\
\text { Helenab } \\
\text { Valley }\end{array}$ & $\begin{array}{l}\text { Hg/day } \\
\text { East } \\
\text { Helena }\end{array}$ & References \\
\hline $\begin{array}{l}\text { Meat, fish, poultry } \\
\text { Vegetables, potatoes } \\
\text { Fruits, juices } \\
\text { Dairy products, eggs } \\
\text { Grain products } \\
\text { Fats, oils (coffee, tea) } \\
\text { Sugars, sweeteners } \\
\text { Water and beverages }\end{array}$ & $\begin{array}{r}245 \\
434 \\
179 \\
486 \\
177 \\
81 \\
149 \\
1270\end{array}$ & $\begin{array}{l}0.03-0.054 \\
0.038-0.090 \\
0.040-0.070 \\
0.021-0.028 \\
0.026-0.211 \\
0.01-0.04 \\
0.04 \\
0.01\end{array}$ & $\begin{array}{r}11.9 \\
31.5 \\
12.0 \\
13.3 \\
21.8 \\
2.7 \\
6.0 \\
12.7\end{array}$ & $\begin{array}{r}12.3 \\
69.2 \\
11.4 \\
13.3 \\
21.8 \\
2.7 \\
6.0 \\
12.7\end{array}$ & $\begin{array}{r}15.5 \\
109.4 \\
13.0 \\
13.3 \\
21.8 \\
2.7 \\
6.0 \\
12.7\end{array}$ & $\begin{array}{l}7,40,27 \\
28,40,7,9,54 \\
9,54 \\
16,55 \\
28 \\
9 \\
9\end{array}$ \\
\hline Total from food & 1751 & & 99.2 & 136.7 & 181.7 & \\
\hline $\begin{array}{l}\text { Total including water } \\
\text { and beverages }\end{array}$ & & & 111.9 & 149.4 & 194.4 & \\
\hline
\end{tabular}

aecause of differences in the amount of consumption of varlous foods within a category, an average of the range of concentrations of cadnium in foods cannot be used. This becomes obvito.1s when food categories are further broken down into individual items; and fresh vs. processed foods.

bEast Helena and Helena Valley figures are based on the assumption that only $12^{\prime \prime}$ of the garden vegetables consumed there are grown locally and that the other $88^{\circ}$ of the diet is shipped in frcm other areas. 8 
rather than $2.0-2.5 \mathrm{~kg}$ per day as uswally reported for the United States. 7.9.16 Extrapolation from intake values in Table 3.42 to those arising from intake of $2.0-2.5 \mathrm{~kg}$ per day gives the following daily intake of cadaiun:

$\begin{array}{lll}\text { Average U.S. } & 128-160 . .3 \\ \text { Helena Valley } & 170-213.9 \\ \text { East Helena } & 222-278.9\end{array}$

\subsection{Standards}

There are no standards set for cadwium in food products or ambient air; however, a Morld Health Organization Report on food additives proposed an intake 1 imit of 400-500 ..g Cd per week. ${ }^{17}$ A threshold limit value (TLV) of $100:-9 / \mathrm{m}^{3}$ of air is established for occupational exposure to cadmiun. 18,19 The maximum permissible concentration of cadisium in drinking water is $0.01 \mathrm{ppm}(10-9 / 1) .20$

CHAPTER 4. CUNEX APPLICATION

\subsection{Atnospheric Transport Model}

A brief description of the atmospheric transport model used at ORAL was given in Section 2.1 .

\subsubsection{Input Data}

Input data necessary to apply CUnXX methodology to cadnium release from the smelter complex in East Helena, Montana, were obtained from the open literature. Source data were taken from Ref. 8. The two sources considered, the hierican Smelting and Refining Company (ASARCO) lead smelter and the Anaconda slag processing facility, are located side-byside in East Helema. Table 4.1.1.1 lists the source data. 
Table 4.1.1.1. Source data for East Helema smelter area

\begin{tabular}{|c|c|c|}
\hline & Asneco & Anaconda \\
\hline $\begin{array}{l}\text { Stack height } \\
\text { Stack radius } \\
\text { Stack gas velocity } \\
\text { Stack gas teaperature } \\
\text { Particulate emissions } \\
\text { Particle size } \\
\text { Particle density } \\
\text { Cd concentration in } \\
\text { particulate emissions }\end{array}$ & $\begin{array}{l}122 \mathrm{~m} \\
2.44 \mathrm{~m} \\
8.2 \mathrm{~m} / \mathrm{sec} \\
127^{\circ} \mathrm{C} \\
56 \mathrm{~g} / \mathrm{sec} \\
\text { unknownd } \\
\text { unknown b } \\
200-1000 \mathrm{ppm} c\end{array}$ & $\begin{array}{l}36 \mathrm{~m} \\
1.38 \mathrm{~m} \\
2.1 \mathrm{~m} / \mathrm{sec} \\
121^{\circ} \mathrm{C} \\
112 \mathrm{~g} / \mathrm{sgC} \\
\text { unknom } \\
\text { unknown } \\
200-1000 \mathrm{ppm}\end{array}$ \\
\hline \multicolumn{3}{|l|}{ Plune rise parameters } \\
\hline $\begin{array}{l}\text { PKAPph d } \\
\text { QKAPPA }\end{array}$ & $\begin{array}{l}877 \\
235\end{array}$ & $\begin{array}{l}155 \\
100\end{array}$ \\
\hline
\end{tabular}

${ }^{a}$ Simulations made for several particle diameters $(0.1,1.0$, 5.0, 10.0, 20.0;). pounds).

bAssumed to be $7 \mathrm{~g} / \mathrm{cm}^{3}$ (average density of $\mathrm{Cd}$ and $\mathrm{Cd} \mathrm{com}-$

c 1000 ppon used in calculations.

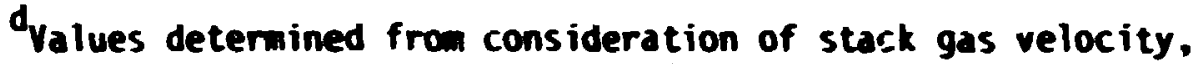
stack radius, stack gas temperature, wind speed and other factors and used to calculate increase in effective stack height ( $p$ lune rise) due to buyancy of the plume (Culkowski and Patterson). 5

Meteorological data given in Ref. 8 included monthly wind rose data for six velocity groups ranging from $0-12.5 \mathrm{~m} / \mathrm{sec}$, perrent occurrence of stability classes A through $F$, average monthly and yearly rainfall and average yearly rainfall intensity.

Terrain surrounding the smelter complex was assumed to be grassland with a surface roughness factor of $0.15 \mathrm{~m}$. ${ }^{4}$ Receptor points were uniformly spaced, 8 each at distances of 1 mile and 2 miles, and 16 each at distances of 4 miles and 8 miles, for a total of 48.

\subsubsection{Output Data}

Output from ATM includes wet and dry deposition values and air concentrations of cadinium at each of the 48 receptor points for each 
quarter of the year. Wet and dry deposition values are nearly equal. Tables 4.1.2.1 and 4.1.2.2 list total depositions and air concentrations of cadium (5 . particle) for each quarter, plus a yearly average, as a function of distance and direction from the smelter. In genera:, seasonal deviation is less than 10: of the average. Yearly averages in Tables 4.1.2.1 and 4.1.2.2 are plotted in Figs. 4.1.2.1 and 4.1.2.2 to show spatial distribution. Values are highest toward the east since the wind blous 45: of the time from the und to usu sectors. At a distance of 8 wiles, values to the east are five to eight times higher than values to the west. Figures 4.1.2.3 and 4.1.2.4 show how air concentrations and depositions of cadaiu change as a function of particle size and distance on a straight line east from the smelter complex. The curves for 0.1 is particles are not shown because they are close to the ones for $1 \%$ particles. There is a decrease of one to two orders of magnitude as the distance increases from 1 to 8 miles. Table 4.!.2.3 gives yearly deposition averages for all five particle sizes assuned. It is apparent that the simulated values for cadmium deposition and air concentration are quite dependent on the assumed particle size. At a distance of 1 mile east, deposition of $20 \mu$ particles is about $20 t$-mes as great as for 1 u particles. At 8 miles, there is less than a faztor of 4 difference since larger particles are depleted from the plune. At a distance of 1 mile east, there are more 20 is particles per unit yolune of air than smaller sizes wile at 8 miles $5 \mu$ particles are most abundant.

\subsubsection{Comparison with Measurenents}

Partial validation of ATM simulations for the smelter area is possible through comparison of the results with data in the EPA report 8 (see Table 4.1.3.1). Within a radius of 1 mile of the smelter measured cadiutum depositions ranged from 1 to $4 \mathrm{mg} / \mathrm{m}^{2} / \mathrm{month}$. Simulated results at 1 mile east of the smelter ranged $r \mathrm{mom} 0.7 \mathrm{mg} / \mathrm{m}^{2} /$ month for a $1 \mathrm{is}$ particle to $15 \mathrm{mg} / \mathrm{m}^{2} /$ month for a $20 \mathrm{u}$ particle. Thus, simulated results for 1-10 4 jirticles compare favorably with experimental data. Within 
Table 4.1.2.1. Deposition of cadaiu around Helena smelter area

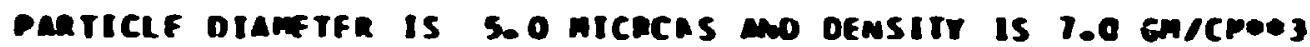

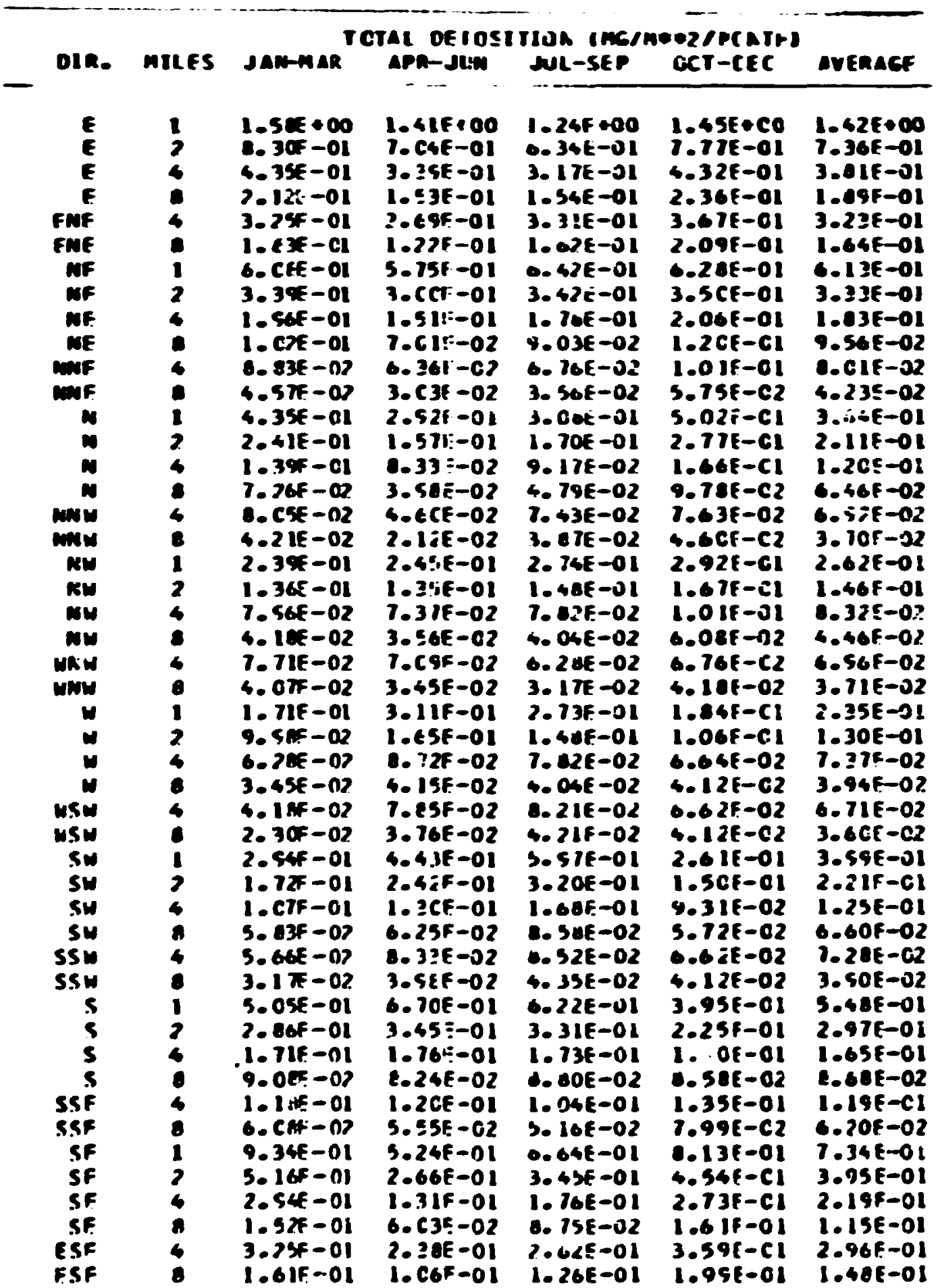


Table 4.1.2.2. Air concentrations of cadviu around inlens selter ares

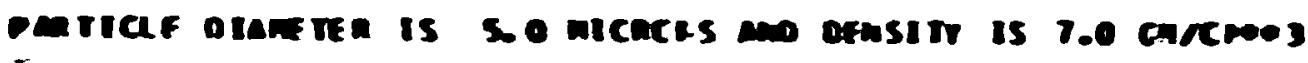

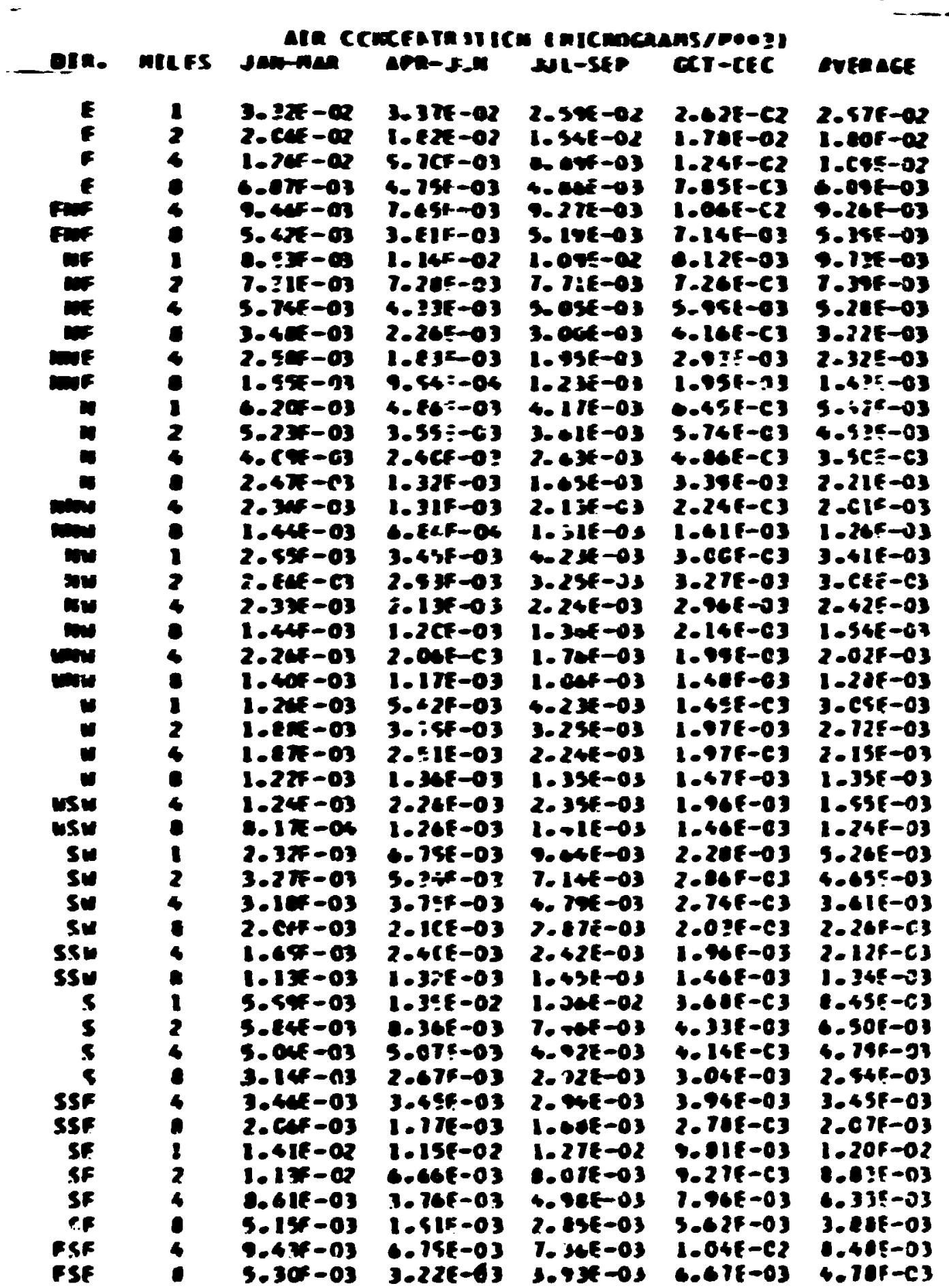




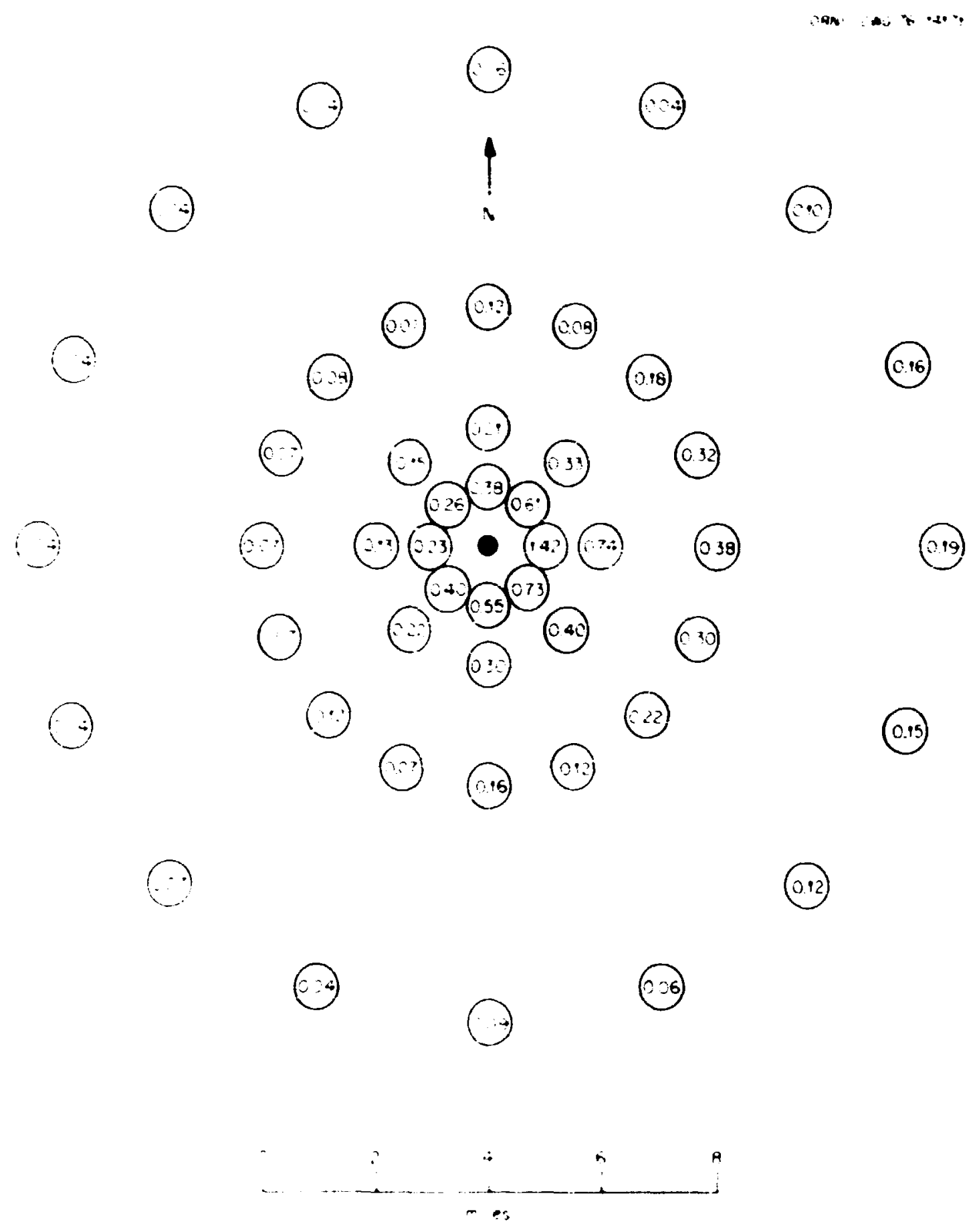

Fig. A.1.2.1. Average deposition of cadmium (5i) around East Helena smelter $\left(\mathrm{mg} / \mathrm{m}^{2} / \mathrm{month}\right)$. 


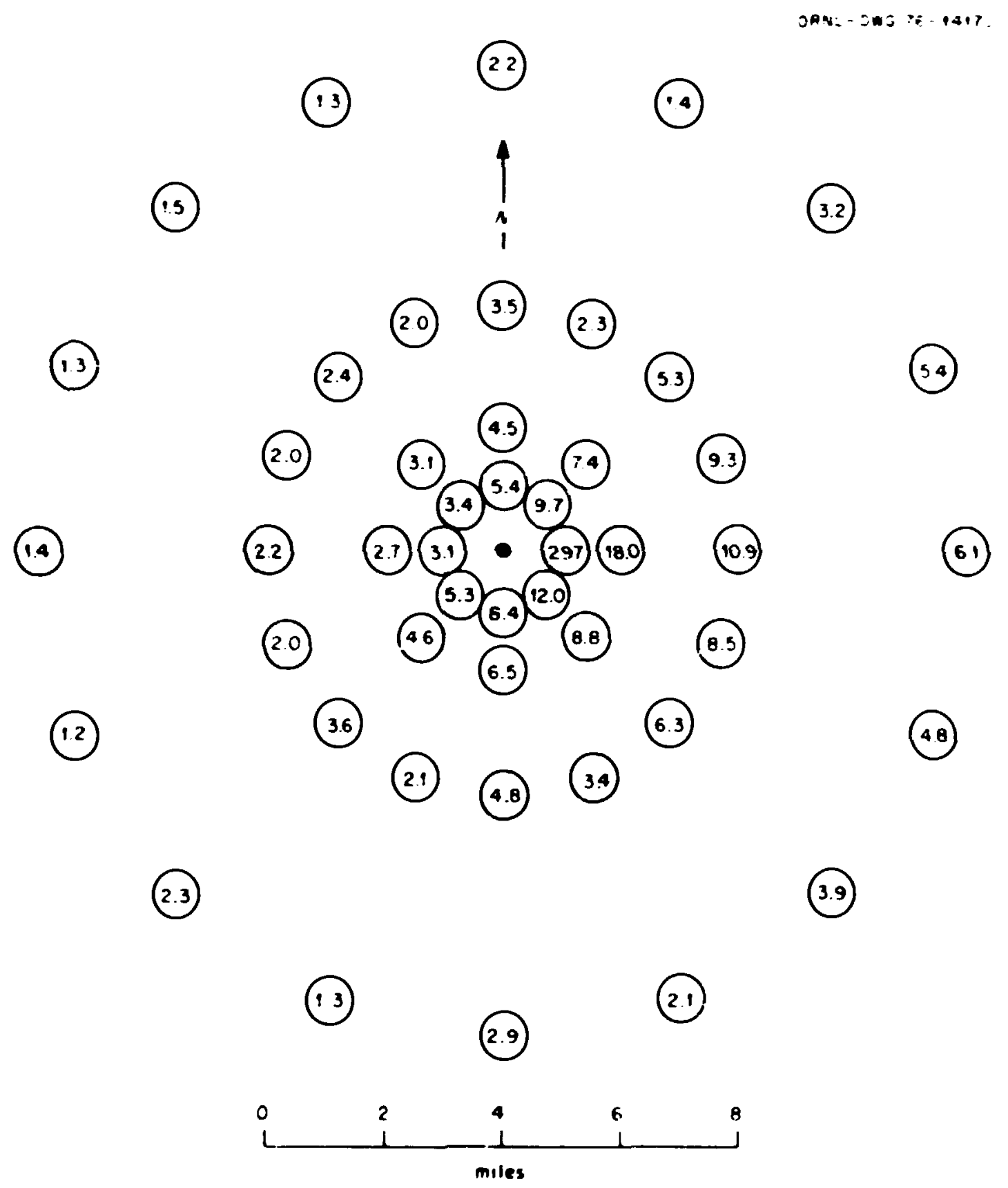

(4)

SAN: - 20 $20-1417$

Fig. 4.1.2.2. Average air concentration of cadmium (5n) around East Helena smelter $\left(n G / \mathrm{m}^{3}\right)$. 


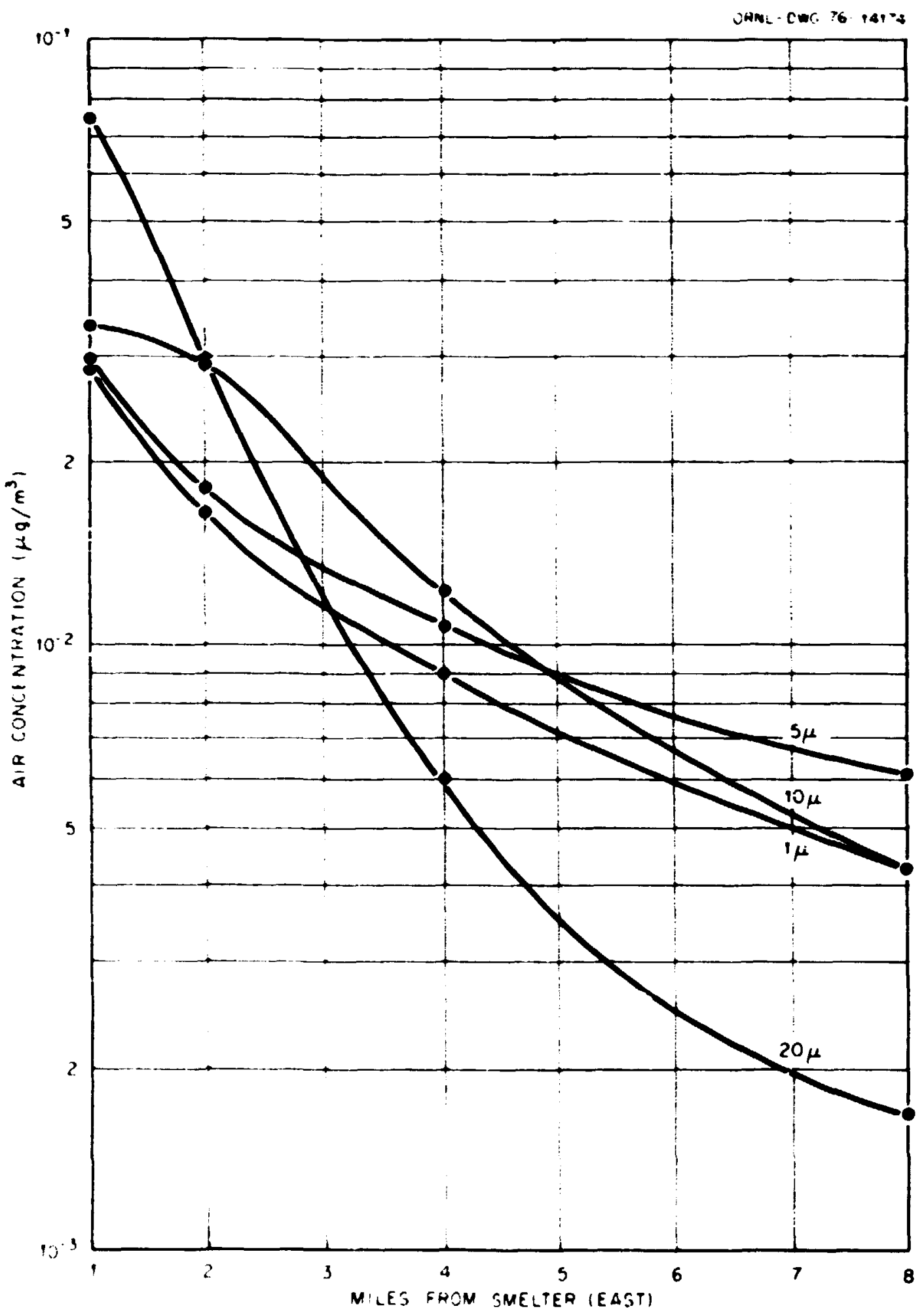

Fig. 4.1.2.3. Air concentration of cadmium around East Helena smelter area as a function of particle size and distance. 


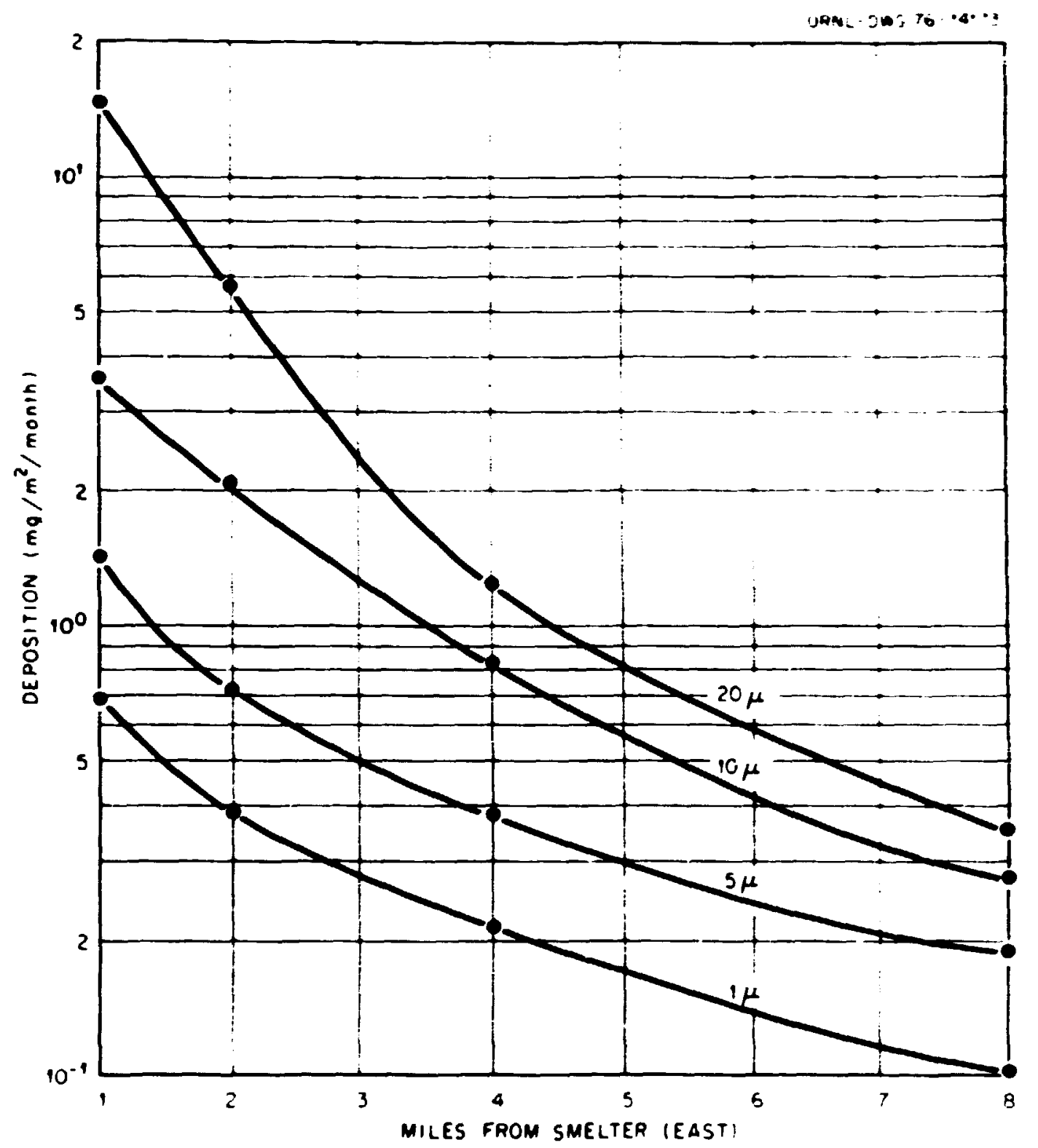

Fig. 4.1.2.4. Deposition of cadmium around East Helena smelter as a function of particle size and distance. 
Table 4.1.2.3. Deposition of cadnium around Helena smelter area

AUFAAGE TEARLT CEFCSITICA IAG/MEA $2 /$ ACATHI

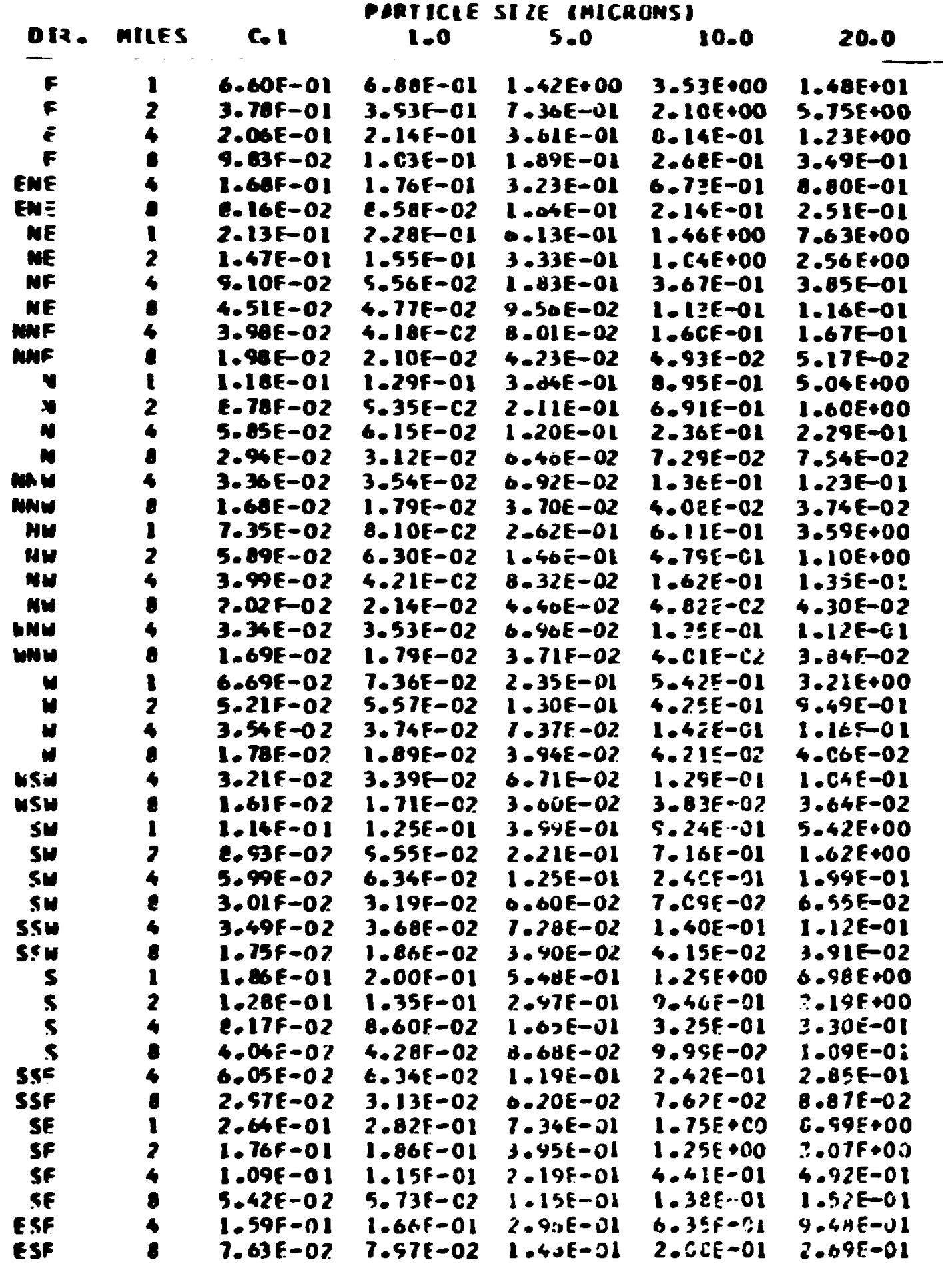


Table 4.1.3.i. Cadnium concentrations in area around East Helena

Cadnium concentration

\begin{tabular}{|c|c|c|}
\hline & Heasured & Calculated \\
\hline $\begin{array}{l}\text { Deposition } \\
\left(\mathrm{mg} / \mathrm{m}^{2} / \text { month }\right)\end{array}$ & $\begin{array}{l}1-4 \text { ( } 1 \text { mile radius } \\
\text { of smel ter) }\end{array}$ & $\begin{array}{l}0.7 \text { ( } 1.0 \text { - particle - } 1 \\
\text { mile east of smelter) }\end{array}$ \\
\hline & $\begin{array}{l}0.1-1 \text { (within } 60 \text { square } \\
\text { miles around East Helena) }\end{array}$ & $\begin{array}{l}0.1-0.3(1-10-\text { particles } \\
8 \text { miles east of smelter })\end{array}$ \\
\hline $\begin{array}{l}\text { Air concentration } \\
\left(\mu g / 100 \mathrm{~m}^{3}\right)\end{array}$ & 6-29 (within East Helena) & $\begin{array}{l}\text { 3-7 (1-20 . particle } 1 \\
\text { mile east of smelter) }\end{array}$ \\
\hline
\end{tabular}

60 square miles around the smelter, levels of 0.1 to $1 \mathrm{mg} / \mathrm{m}^{2} /$ month $\mathrm{kere}$ measured. At a distance of 8 miles east, the simulated results were 0.1 to $0.3 \mathrm{mg} / \mathrm{m}^{2}$ imonth for 1-10:3 particles. Measured 24-hour average a ir concentrations of cadaium at various locations within East Helena ranged from 6.0-29.0 ug/100 $\mathrm{m}^{3}$, wile simulated results at a distance of $1 \mathrm{mile}$ east ranged from $3.0-7.0 \mu \mathrm{g} / 100 \mathrm{~m}^{3}$ for $1-20:$ particles.

Thus, the ATM appears to be giving reasonable results for cadium concentrations in the area surrounding the East Helena Smelter. These data may be used to estinate annual additions to the soil or depositions on crops at specified locations within an 8 mile radius.

\subsection{Terrestrial Transport Model}

Starting with given cadnium ground deposition rates, obtained from monitoring data for the U.S. and from the ATM output for East Helena, TERMOD simulated cadnium intake by the average U.S. adult and by an East Helena adult. Pathways considered were air inhalation, milk, beef, and solid-food consumption, and direct deposition on truck crops (uptake of truck crops is after washing wich is assumed to renove 75 of the 
cadniva). 38 The model applies only for soil concentrations of cadmium - io ppa. Crop production is reduced for higher soil concentrations (Appendix II).

\subsubsection{Input Data}

The input to the model is a constant ground deposition rate of 15 $.9 \mathrm{Cd} / \mathrm{m}^{2}$-day wich corresponds to an average air concentration of 0.025 $-9 / \mathrm{m}^{3}$ and a deposition velocity of $600 \mathrm{~m} /$ day. The air concentration is a typical value for areas near large cities in the U.S. ${ }^{9}$ Therefore, the model predictions are for current, equilibrium (background) concentrations in soil, grass, milk, and beef and current up'akes of cadmiun via the pathays considered. A ground deposition of $86 \mathrm{jg} \mathrm{cd} / \mathrm{m}^{2}$-day at 1 wile east of the smeiter was obtained from the ATM output for the East Helena simulation. This ground deposition corresponds to an air concentration of $0.14 \mathrm{~g} / \mathrm{m}^{3}$ for a deposition velocity of $600 \mathrm{~m} /$ day.

The model was run for two values (10 years and 50 years) for the half-time of cadnium in subsurface soil pool and pasture soil (Appendix II).

A literature survey was made to find reasonable values for all TEAOMD input parareters and to insure that the calculated transfer coefficients were reasonable. The only parameter not specifically calculated for cadniun or verified to apply to cadmium was ' $s, p$, the coefficient associated with transfer from soil surface to subsurface soil pool. A value of 0.0693 days $^{-1}$ was assigned to this coefficient. A sensitivity study was conducted to determine the importance of $\tau_{s, p}$ to model calculations. It was found that model calculations are relatively insensitive to this parameter.

The model simulation began with cadnium present only in the air. Build-up of cadnium in other compartments (from initial values of zero) was calculated as a function of time after this constant cadmium concentration appeared in air. Cadmium concentrations in these compartments were also calculated as a function of time after an impulse source of cadnium was in the air. 


\subsubsection{Output Data}

Equilibrium concentrations in various compartments resulting from ground deposition rates of $15 ; \mathrm{g} \mathrm{Cd} / \mathrm{m}^{2}$-day and $86 ; \mathrm{g} \mathrm{cd} / \mathrm{m}^{2}$-day are shown in Table 4.2.2.1.

Table 4.2.2.1. Equilibrium cadniun concentrations in various compartments

\begin{tabular}{|c|c|c|c|c|}
\hline \multirow{3}{*}{ Compartment } & \multicolumn{4}{|c|}{ Equilibrium concentration (ppm) } \\
\hline & \multicolumn{2}{|c|}{$\begin{array}{l}\text { 10-year half-time } \\
\text { in soil }\end{array}$} & \multicolumn{2}{|c|}{$\begin{array}{l}\text { 50-year half-tim? } \\
\text { in soil }\end{array}$} \\
\hline & $15^{a}$ & $86^{a}$ & $15^{\mathrm{a}}$ & $86^{a}$ \\
\hline $\begin{array}{l}\text { Surface food } \\
\text { Subsurface soil pool } \\
\text { Grass } \\
\text { Pasture soil } \\
\text { Milk } \\
\text { Beef }\end{array}$ & $\begin{array}{l}0.07 \\
0.27 \\
0.46 \\
0.24 \\
0.002 \\
0.06 \\
\end{array}$ & $\begin{array}{l}0.40 \\
1.55 \\
2.64 \\
1.38 \\
0.011 \\
0.34 \\
\end{array}$ & $\begin{array}{l}0.07 \\
1.30 \\
0.51 \\
1.16 \\
0.003 \\
0.07\end{array}$ & $\begin{array}{l}0.40 \\
7.45 \\
2.92 \\
6.65 \\
0.017 \\
0.40 \\
\end{array}$ \\
\hline
\end{tabular}

Equilibrium intakes by reference $\operatorname{man}^{43}$ for constant ground deposition rates of $15 \mu \mathrm{g} \mathrm{Cd} / \mathrm{m}^{2}$-day and $86 \mu \mathrm{gd} / \mathrm{m}^{2}$-day are snown in Table 4.2.2.2.

Table 4.2.2.2. Equilibrium intakes by reference man

\begin{tabular}{|c|c|c|c|c|}
\hline \multirow{3}{*}{$\begin{array}{l}\text { Pathway } \\
\text { or } \\
\text { Compartment }\end{array}$} & \multicolumn{4}{|c|}{ Intake (lg/day) } \\
\hline & \multicolumn{2}{|c|}{$\begin{array}{l}\text { 10-year half-time } \\
\text { in soil }\end{array}$} & \multicolumn{2}{|c|}{$\begin{array}{l}50 \text {-year half-time } \\
\text { in soil }\end{array}$} \\
\hline & $15^{a}$ & $86^{\mathrm{a}}$ & $15^{\mathrm{a}}$ & $86^{\mathrm{a}}$ \\
\hline $\begin{array}{l}\text { Subsurface soil pool } \\
\text { Surface food } \\
\text { Beef } \\
\text { Mflk } \\
\text { Air inhalation }\end{array}$ & $\begin{array}{l}67 \\
18 \\
20 \\
2.3 \\
0.5^{b}\end{array}$ & $\begin{array}{r}384 \\
103.1 \\
114.6 \\
13.2 \\
3 c^{2}\end{array}$ & $\begin{array}{l}326 \\
18 \\
22 \\
2.6 \\
0.5^{b}\end{array}$ & $\begin{array}{c}1870 \\
103 \\
126 \\
15 \\
3 c\end{array}$ \\
\hline Total & 108 & 618 & 369 & 2115.0 \\
\hline
\end{tabular}

${ }^{a}$ Deposition rates in $\mu \mathrm{g} / \mathrm{m}^{2}$-day.

bAir concentration $0.025 \mathrm{jg} / \mathrm{m}^{3}$.

CAtr concentration $0.14 \mathrm{\mu g} / \mathrm{m}^{3}$. 


\subsubsection{Comparison with Measurements}

A ground deposition rate for cadium of $1-4 \mathrm{mg} / \mathrm{m}^{2}$-month or $30-133$ $\therefore g / m^{2}$-day occurred on a 1.5 sq-aile area around the East Helena industrial complex. Equilibrium uptake rates and plots given here apply for a deposition rate of $15 \mathrm{ig} / \mathrm{m}^{2}$-day. Thus, TERmo predicts an equilibriu uptake of cadaiu by a "fencepost" reference $\operatorname{man}^{43}$ in East Helena of [(30-133)/15] $\times 107.8=216-956 ;$ g/day for a 10-year malf-time in soil and $[(30-133) / 15] \times 369=738-3272$ for a 50-year half-time in soil. The range calculated from food concentrations ws $197-811$ ig/day for an average East Helena adult with 876 as the reasomable, maxima daily uptake. The corresponding equilibriu subsurface soil pool concentration would be $[(30-133) / 15] \times 0.27=0.54-2.4$ ppon for a 10-year half-tive in soil and $[(30-133) / 15] \times 1.30=2.6-11.5 \mathrm{ppom}$ for a 50-year half-tive in soil. Note that the model will not apply for cadaiu concentrations in soil :10 ppm (Appendix II). The ground deposition rate of $86 \mathrm{wg} \mathrm{cd} / \mathrm{m}^{2}$ day calculated by the ATM falls about midway in the range deternined by actual measurements.

Figures 4.2.3.1 through 4.2.3.6 show calculated cadmiun uptake by reference man ${ }^{43}$ under a variety of conditions as described in each figure.

\subsection{Calculation of Cuncx Index}

A CUnEX index for the maximally exposed individual in the area surrounding the sanelter complex in East Helena, Hontana, is calculated based on the following data and assuptions (see Appendix II):

1. particle size $=10 \mu$,

2. deposition velocity $=600 \mathrm{~m} / \mathrm{day}$,

3. 100: of diet obtained locally,

4. $2112 \mathrm{\mu g} \mathrm{Cd} /$ day in diet from $0.14 \mathrm{\mu g} \mathrm{cd} / \mathrm{m}^{3}$ in air $=15,000$ $\frac{\mu g C d}{d a y}$ in diet from $1 \mu \mathrm{g} / \mathrm{m}^{3}$ in air (50-year cadaium half-timp in soil), 


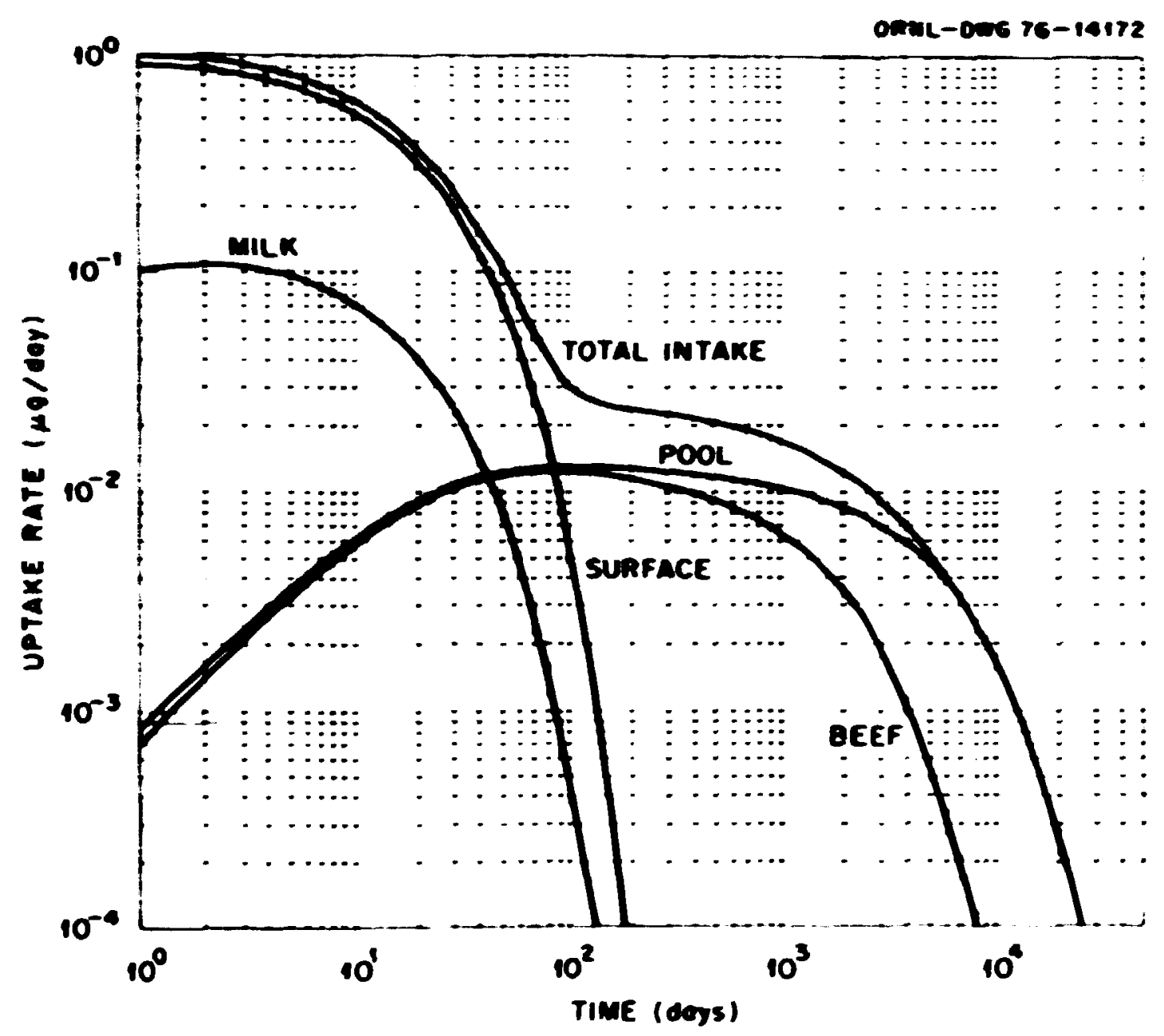

Fig. 4.2.3.1. Intake rate of cadwiun vs time after an inpulse, ground deposition of $15 \mathrm{wg} / \mathrm{m}^{2}$. Intake is by reference man 43 whose diet consists of $250 \mathrm{dry}$ grams of regetables/day, $1.0 \ell$ milk/day, 300 wet grans of bef/day and a total, solid food intake (less fish, beef, and vegetables) of 2500 wet grams/day. The half-time for loss of cadriun from the subsurface soil $\mathrm{pool}$ and pasture soil was 10 years. 


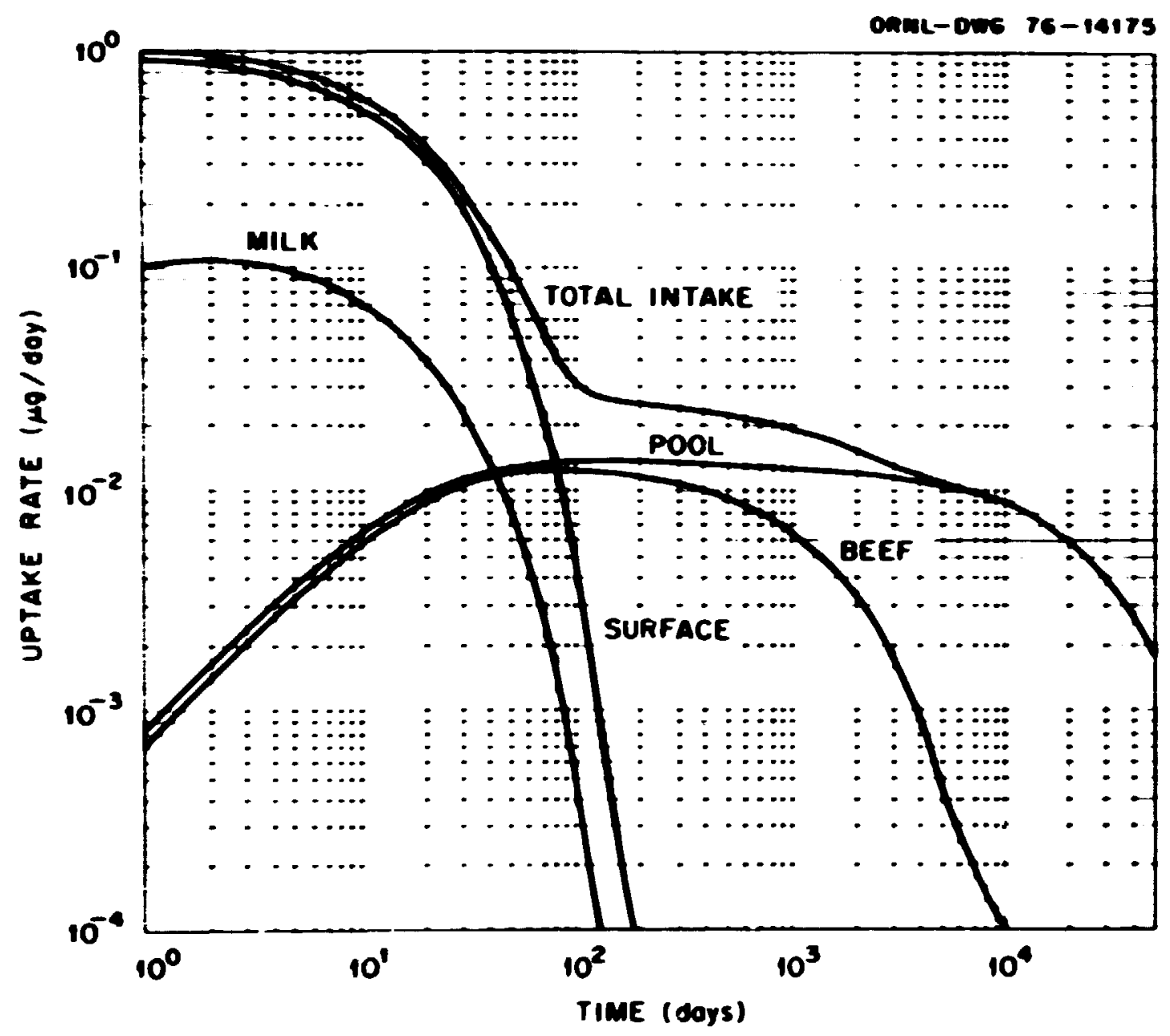

Fig. 4.2.3.2. Intake rate of cadaiua vs time after an inpulse, ground deposition of $15 \mathrm{\mu g} / \mathrm{m}^{2}$. Intake is by reference man. 43 The halftime for loss of cadiuium from the subsurface soil pool and pasture pool mas 50 years. 


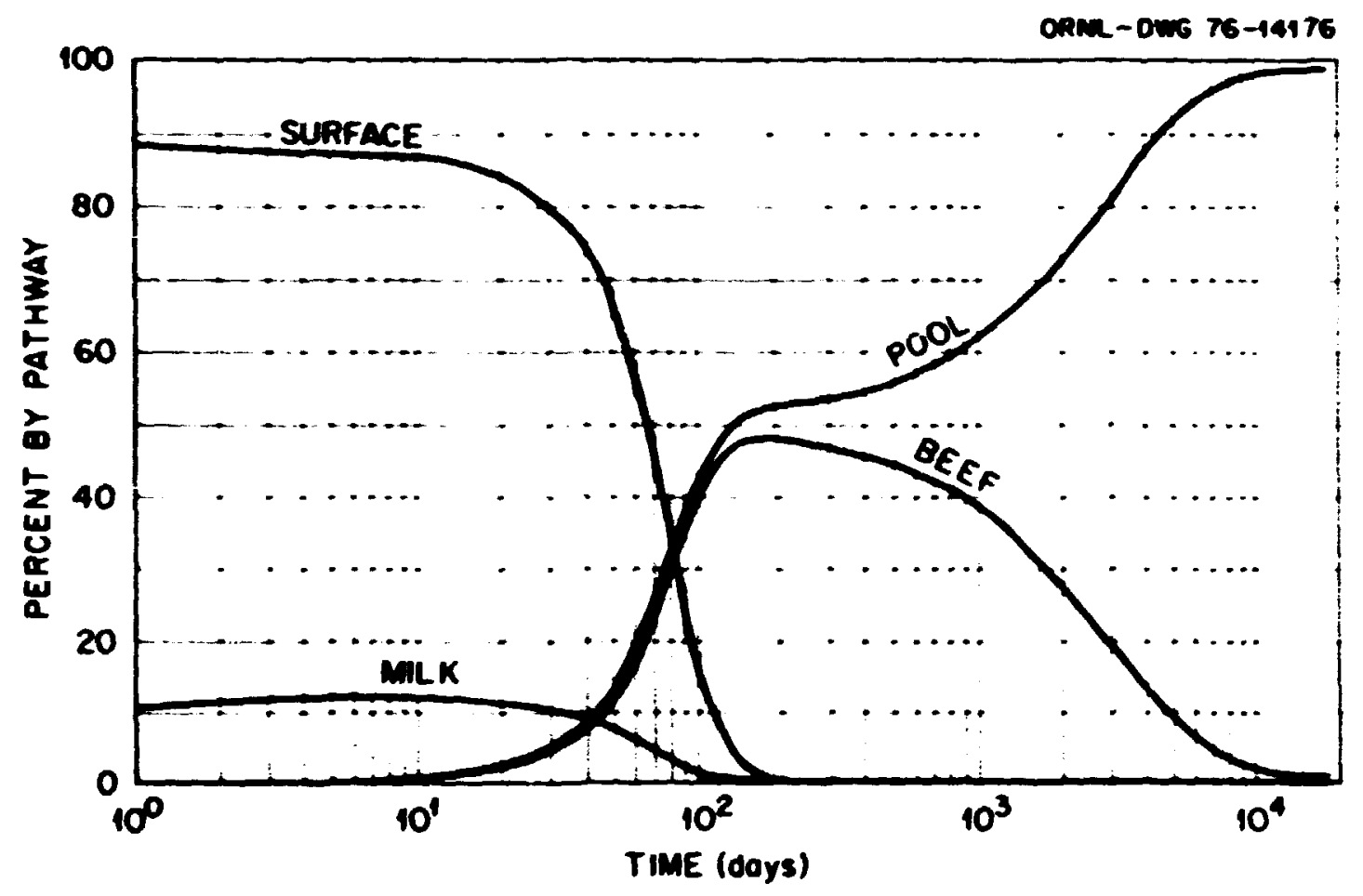

Fig. 4.2.3.3. Percent of the daily cadnium intake from each pathway as a function of time after an impulse, ground deposition of $15 \mathrm{\mu g} / \mathrm{m}^{2}$. Intake is for reference man. 43 The haif-time for loss of cadnium from the subsurface soil pool and pasture soil was 10 years. See fig. 4.2.3.1 for intake rates in $\mu \mathrm{g} /$ day. 


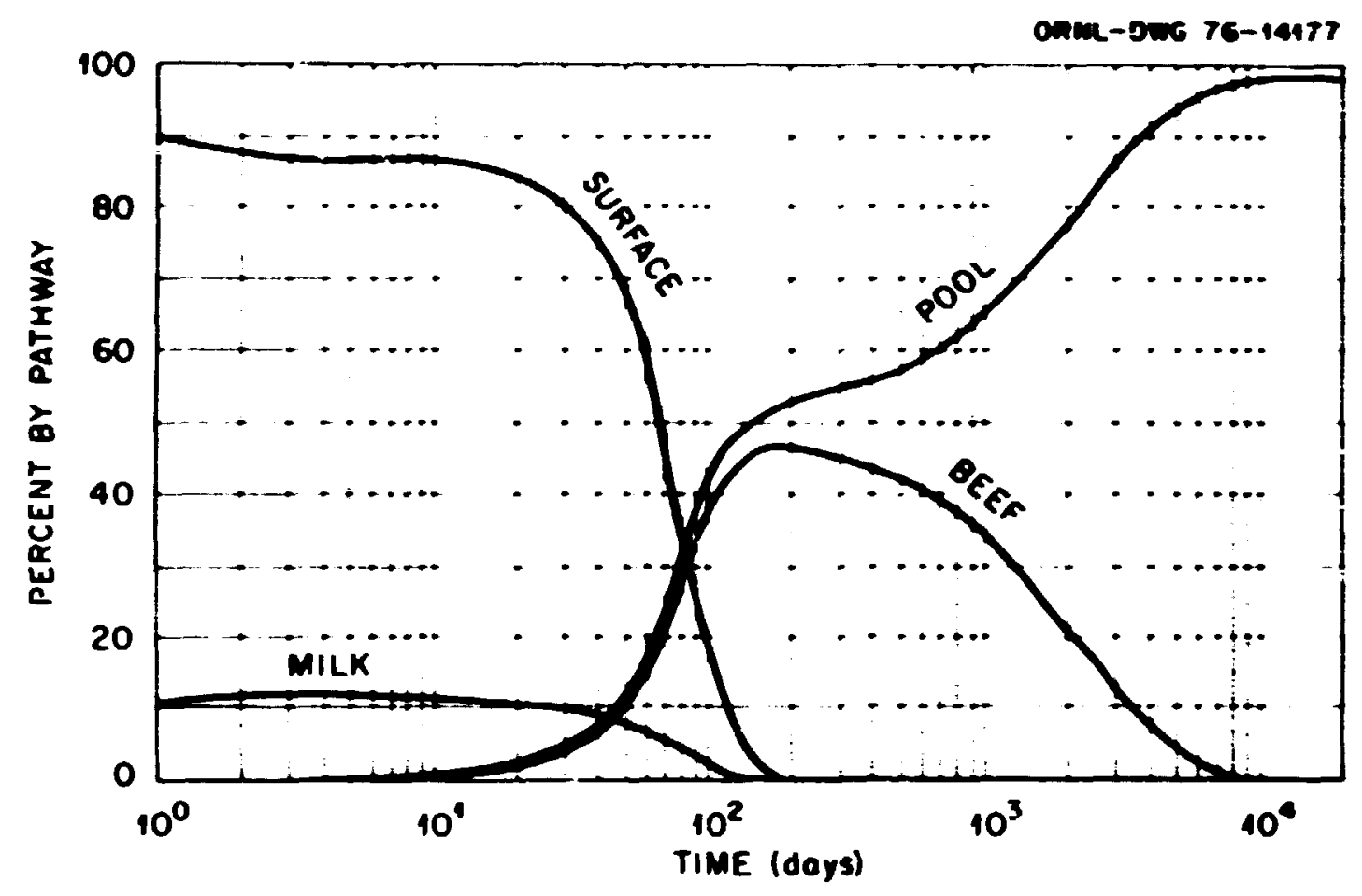

Fig. 4.2.3.4. Percent of the daily cadmium intake from each pathway as a function of time after an impulse, ground deposition of $15 \mathrm{\omega g} / \mathrm{m}^{2}$. Intake is for reference man. ${ }^{43}$ The half-time for loss of cadmiun from the subsurface soil pool and pasture soil was 50 years. See Fig. 4.2.3.2 for intake rates in $\mathrm{hg} / \mathrm{day}$. 


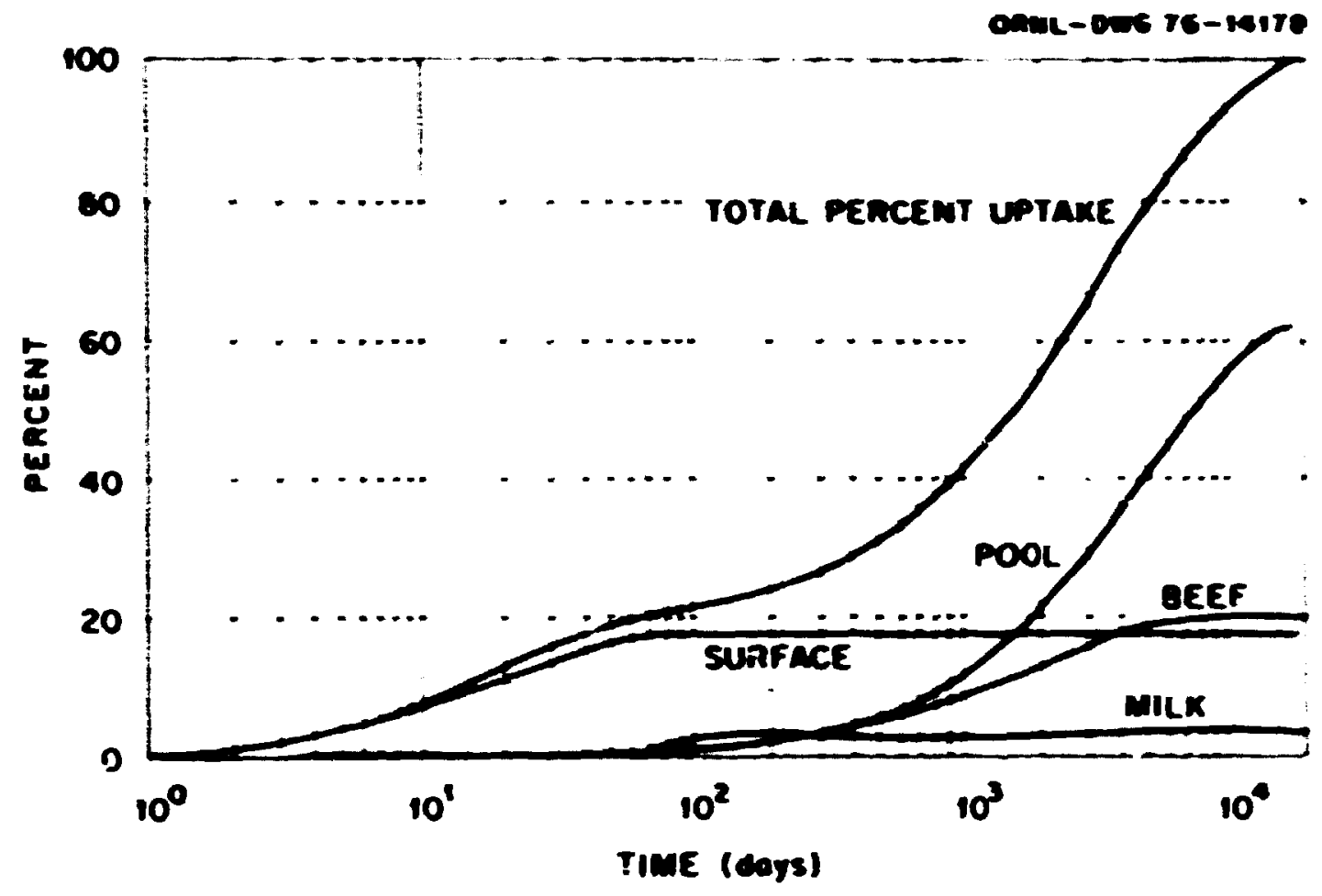

Fig. 4.2.3.5. Percent of the total, 50-year intake of cadiuiv through each pathoy up to time $t$ after an inpulse, ground deposition of $15 \mathrm{\mu g} / \mathrm{m}^{2}$. Also, aultiplication by 1.05 corverts these plots to the intake rate (ug/day) of cadaica as a function of time after a constant ceposition source of $15 \mathrm{ig} / \mathrm{m}^{2}$-day first appears. Inputs are for reference man. 43 The half-time for loss of cadicic fros the subsurface soil pool and pasture soil ws 10 yeurs. 


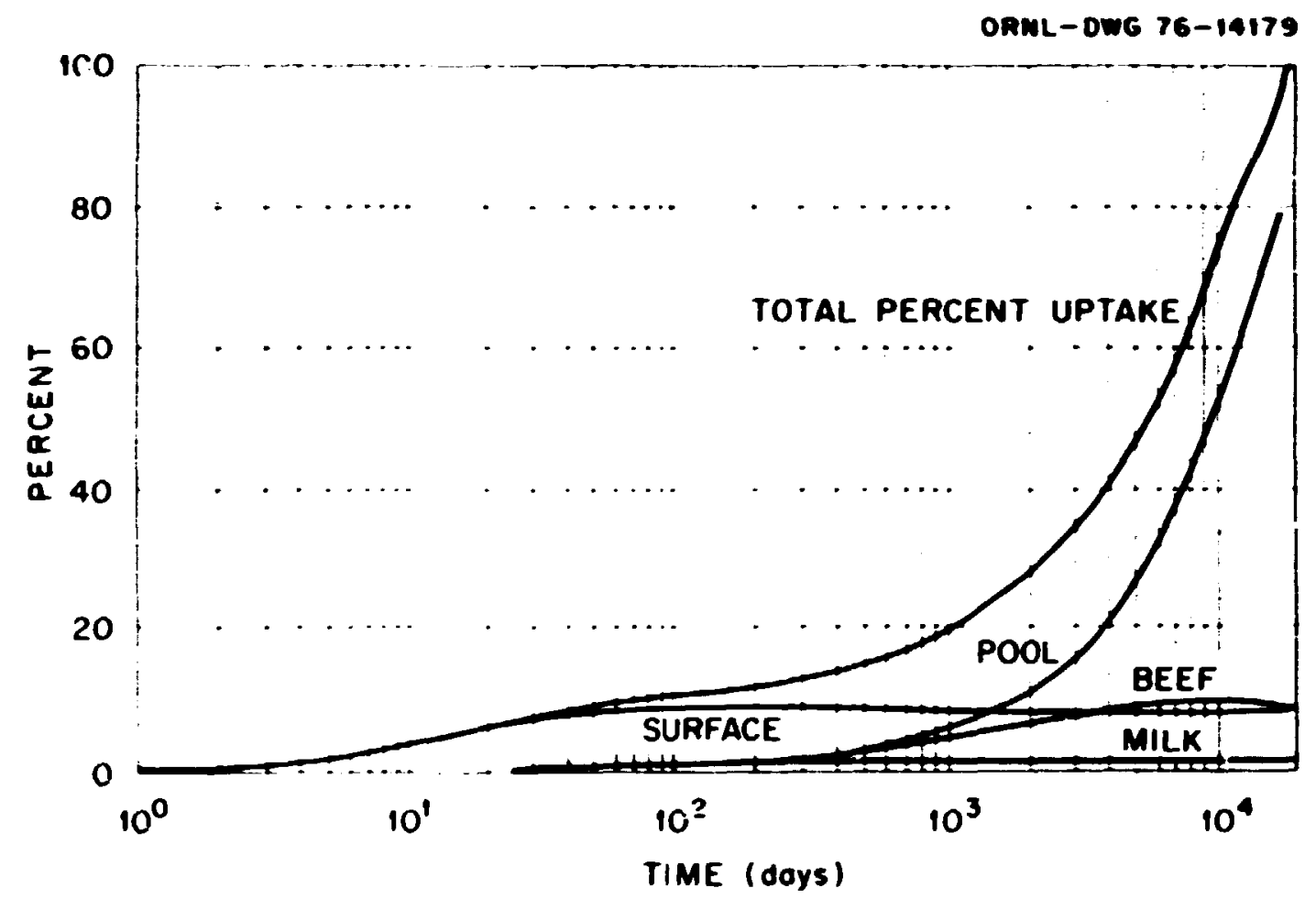

Fig. 4.2.3.6. Percent of the total, 50-year intake of cadmium througl, each pathway up to time $t$ after an impulse, ground deposition of $15 \mathrm{\mu g} / \mathrm{m}^{2}$. Also, multiplication by 2.12 converts these to the intake rate (ug/day) of cadmium as a function of time after a constint deposition squrce of $15: . \mathrm{g} / \mathrm{m}^{2}$-day first appears. Inputs are for reference man. 43 The halftime for loss of cadmium from the s!ıbsurface soil pool and pasture soil was 50 years. 
5. I $\mathrm{ug} \mathrm{Cd} / \mathrm{m}^{3}$ inhaled $=100 \mu \mathrm{g} \mathrm{Cd} / \mathrm{g}$ in kidrey cortex after 50 years,

6. $1 \mu \mathrm{g} \mathrm{Cd} /$ day in diet $=1 \mu \mathrm{g}$ in kidney cortex after 50 years,

7. Selected limit $=200 \mathrm{\mu g} \mathrm{Cd} / \mathrm{g}$ wet weight of kidney cortex in 50 years,

8. total weight of kidneys $=300 \mathrm{~g}$, and

9. half-time of cadmion in body $=36$ years.

Inhalation and ingestion are the routes of exposure considered, therefore Eq. $(1.2 .2)$ was used with $f_{A W} V_{W} f_{W}=k f_{2}=0$.

$$
c_{A}=\frac{Q_{L}}{\left(v_{A} f_{a}+f_{A F^{M}} F_{W} f_{w}\right) \tilde{R}},
$$

where

$$
\begin{aligned}
& Q_{L} \quad=200 \mathrm{\mu g} / \mathrm{g} \text { wet weight kidney cortex }=4 \times 10^{4} \mathrm{\mu g} \text { in } \\
& \text { total kidneys, } \\
& v_{A}=20 \mathrm{~m}^{3} / \text { day, } \\
& f_{a}=0.25 \times 1 / 3=0.083 \text {, } \\
& f_{w}=0.05 \times 1 / 3=0.017 \text {, } \\
& f_{A F}^{W} M_{F}=15,086 \frac{\mu g}{d g y} \frac{m^{3}}{\mu g} \text {, and } \\
& \widehat{R}^{\prime}=1.2 \times 10^{4} \text { days based upon simple exponential retention } \\
& \text { with } \dot{T}=50 \text { years. }
\end{aligned}
$$

Thus,

$$
C_{\hat{A}}^{\star}=1.3 \times 10^{-2} \frac{\mu g}{\mathrm{~m}^{3}} \text {. }
$$

The CUMEX index calculatec above represerits a cadmium concentration in air low enough to prevent a cacmium related health effect to persons receiving exposure in the study area for a 50-year period. It is a conservative estimate when applied such that if the maximally exposed individual is protected, all otrers will also be protected. The calculated 
CUMEX value of $0.013 \mathrm{jg} / \mathrm{m}^{3}$ is near the average urban cadaiun concentration of $0.02: 9 / \mathrm{m}^{3}$ in air in the U.S. (Table 3.4.1) and about 5-20 times lower than levels actually measured in East Helena $(0.06$ to $0.29 \mathrm{\mu g}$ $\left(d / m^{3}\right)$. Realistically, no individual is likely, over a 50-year period, to breathe ouly air containing the maximum concentration of cadniun or eat food produced only at the site of maximu cadmium deposition. Less conservative CumEX indexes can be calculated if justified by site characteristics. For example, if the area of interest is divided into a grid network and air concentrations are predicted by ATM for each section, individual CUmEX values can be determined for each. An average air concentration could be determined for the area and another CUMEX value calculated. The proportion of total diet produced outside the study area can be considered. Obviously any change in the paraneters of environmental or physiological models will affect CumEX values. The degree of conservatism of resulting values will depend on the degree to which model parameters can be quantified.

\section{CONCLUSION}

Application of the CUMEX index to cadmium release from the smelter complex in East Helena, Montana, has illustrated the potential usefulness of this approach; however, humans are rarely if ever exposed to only one pollutant from one source. The ul timate usefulness of CUMEX will be realized when information allows multi-source, multi-pollutant models to be tested. The most sophisticated and developed modeling system must agree with experiment, but in addition, must suggest better ways to obtain data. The ability to predict the health impact of multi-pollutant exposure will improve as data accumulate. 
APPENDIX 1

MODIF ICATIONS OF TERMOC 


\section{APPENDIX I. MOOIFICATIONS OF TERMOD}

TERGO0 has been described previously in Refs. 1 and 2. Modificatios of the model necessary for CunEX application follow:

The expression for intake by man of elesents from the subsurface soil pool, $\tau, p, m$, was rederived so that it would not depend on the biological half-tine of the element in man. The new expression for $\tau p, m$ is

$$
\left.\tau_{p, m}=10^{3} \frac{T_{D} C_{V}}{P_{\text {eq }}} \quad \text { days }^{-1}\right),
$$

where the factor $10^{3}$ is required for conversion of units $\left(1 \mathrm{~g}=10^{-3} \mathrm{~kg}\right)$,

$T_{D}=$ total daily intake of solid food excluding fish and medt $(2.5 \mathrm{~kg} /$ day $)$;

$C_{y}=$ average background concentration (wet weight) of the element in harvested, sol id food excluding fish and meat $10.05 \mu \mathrm{g} / \mathrm{g}$ for cadmiun), and

$P_{\text {eq }}=$ average background content of elenent in subsurface soil pool per man. For cadniun the value is,

$$
\begin{aligned}
P_{\text {eq }} & =0.5 \mathrm{\mu g} / 9 \times 1.4 \mathrm{~g} / \mathrm{cm}^{3} \times 20 \mathrm{~cm} \times 10^{7} \mathrm{~cm}^{2} \\
& =1.4 \times 10^{8} \mathrm{\mu g}
\end{aligned}
$$

where $0.5 \mu \mathrm{g} / \mathrm{g}=$ average background cadmium concentration in subsurface soil,

$1.4 \mathrm{~g} / \mathrm{cm}^{3}=$ soil density,

$20 \mathrm{~cm} \quad=$ plow layer depth, and

$1 \times 10^{7} \mathrm{~cm}^{2}=$ area of soil required to supply food for one man.

An expression was derived for the transfer of cadmium from pasture soil to pasture grass, ${ }^{\top} r, g^{*}$

$$
\tau_{r, g}=0.1 \frac{V_{c} C_{p}}{A_{g} C_{s} \rho d}\left(\text { days }^{-1}\right),
$$




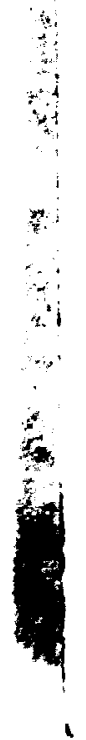


where the factor 0.1 is required for conversion of units $\left(10^{3} \mathrm{~g} / \mathrm{kg} / 1 \mathrm{c}^{4}\right.$ $\left.c^{2} / m^{2}\right)$.

$V_{c}=$ dry weight grass consuption per day by a cow (10 kc/day),

$C_{p}=$ average, background concentration (wet weight) of cadmium in grass $(1.0: \mathrm{g} / \mathrm{g})$,

$A_{g}=$ pasture area per con $\left(10^{4} m^{2}\right)$.

$c_{s}=$ average, background concentration of cadnium in soil 10.5 ig/g),

$\therefore=$ density of soil $\left(1.4 \mathrm{~g} / \mathrm{cm}^{3}\right)$, and

$d=$ plow layer depth $(20 \mathrm{~cm})$. 


\section{APPENOIX II. CAOHIUN REVIEU}

\section{Industrial Sources}

Total release of cadium to the environsent from all sources for 1968 was estimated to be about $2.50 \times 10^{6} \mathrm{~kg}$ to $3.58 \times 10^{6} \mathrm{~kg}$. The actual release may have been greater because an additional $4.99 \times 10^{6} \mathrm{~kg}$ ws either considered as waste or put into permanent use with final disposal unknown. 7

As experted, cadmiun is released to sime degree frum industries involved in its production or use. 7,9 It enters the environment as a byproduct in the refining of zinc and other metals. Combustion of fossil fuel adds to the burden since cadaium is present as a trace contaninant, as does use of cadmium in various industrial products such as alkaline batteries, copper alloys, paints, and plastics. 52 Both airborne and waterborne cadmiu can increase concentrations of cadmium in soil and vegetation, in animal products and huans.

Accusulation of cadmium in the environment may be expected to continue since projections show an $86 \%$ increase in zinc consumption, a $127 \%$ increase in cadmiu use and an increase in coal use in steam plants for power production. 7,23 With increased use of coal, large increases in emissions of trace toxic metals will occur in spite of improved eaissions control technology. Electrostatic precipitators or scrubbers, wich efficiently renove large fly ash particles, are less efficient for vapors and fine particles. A relationship has been shown between concencration and particle size for some trace elements in fly ash. Lead, antimony, cadmiun, selenium, arsenic, chronium, and zinc show clear increas's in concentrations as the fly ash particle size decreases. 24,25 Also because of a slower deposition velocity, fine particles are more widely distributed in the environment. The highest concentrations of these trace elenents are found in particies of a size which deposit in pulmonary regions of the respiratory system where absorption is greatest. 7 
Agricultural Sources

Midespread houn cadaiu exposure ay result fro certain faning practices in food production. Food is, in general, the major source of cadaiu intake by man since plants ay absorb toxic heavy metals along with mineral elements required for growth. Some grains and regetables produced with heavy applications of comerciai fertilizers ccitain relatively high concentrations of cadium. Schroeder and balassa found 9 to $36 \mathrm{ppon}$ cadaiu in phosphate fractions of five fertilizers. 26 Superphosphate contained 7.25 ppa cadiun. Contrywide, 39,902,000 tons of comercial fertilizers were applied in 1970, increasing to 41,582,000 tons in 1972. 27 Grains, wich are often fertilized with phosphate fertilizers, ma accumulate an appreciable mount of cadiun (Table 3.4.2), a situation particularly important because of high wheat consumtion by huans. Schroeder et al. 28 hower, found no signif icant difference in cadaiu content of fertilized and unfertilized plants and, based on a survey of cadaiu in wheat from rural areas. Huffuan and Hodgson 28 concluded that superphosphate fertilizers did not affect cadain levels in plants.

Use of sewage sludges as soil conditioners can contribute to cadaiu so 1 burdens. Linnman et al. determined cadaiu uptake by wheat grom in soil treated with amounts of sewage sludge (cadium content $10 \mathrm{ppm}$ ) varying from 0 to 175 tons/hectare. 11 cadmium uptake increased with increasing sludge addition at all but the highest level used, reaching a maximm of $257+9 \mathrm{ppb}$. Strenström and Lönsjö obtained siailar results in an experiment using sewage sludge containing 5.2 ppo radiolabeled cadaium. 12 Cadniun uptake by wheat increased with increasing sludge addition with 0.0033 of cadaium originally in sludges appearing in mature crops, indicating that even a limited use of sludge my eventuaily produce concentrations of cadmium in agricultural products mich are intolerable in light of the World Heal th Organization recomendations for human intake of $70 \mathrm{\mu g} /$ day. 17 strenström and Vohter made similar observations on cadmiun accumulating in arable land from phosphatic fertilizers, disagreeing with Schroeder et al. 30 
Thenshower found only a wat correlation between plant and soil cadriu concentrations, possibly because cadeiu soil reservoirs are not the only source of cadiun for plants. 10 enother source is particulate contanisation of leaf surfaces from atwospheric pollution. Cadaiucontaining insecticide or fongicide sprays also contribute. ${ }^{31}$ in controlled experinents. cidie concentration of aboveground plant parts ws a function of cadiun concentration of the root eediun where no atospheric source ws available. ${ }^{32}$ Uptake of cadaiu by plants from soil in the matural emiroment is affected by plant soecies, soil type, pH, presence of other wetals and organic meter, wisture, farming practices, and location in re?ation to pollutant sources. $7,9,33,34$

Cadiun is a constituent of compounds routinely used as fungicides on turf and occasionally as helainth suppressants in cattle. 35,36 Use of $\mathrm{CaCl}_{2}$ has been suggested to counteract tobacco mosaic virus. 37 Tobacco is a plant wich accumlates cacium. Little and hartin have shom that only 28; of airborne cadaic deposited on eln trees leaves can be renoved by whing, indicating penetration and uptake of cadium by the leaf. 38 a study by Ross and Stemart indicated a translocation of cadmic to apples from trees which had received a cover spray of cadnium chloride each year for three years. 31 Foliage residues slowly decl ined throughout the season and cadaic acculated in apples as they matured.

It has been found recently that tobacco snoking contributes to daily intake of cadaiu. Smoking one to two packs of cigarettes per cay will increase daily intake of cadais by 2 to 4 , 7,41 Cadaiun in tobacco is derived from soil, fertilizers, and agricultural sprays. For this reason, agricultural practices in the tobacco industry, as well as in the food growing industry, must be carefully evaluated in terms of their ultimate impact on hums.

Environmental Concentration of Cadiun

Concentrations in air

Air in urban areas contained cadmiun at an average level of 0.02 $\mu \mathrm{g} / \mathrm{m}^{3}$. The average nomurban air concentration is $0.003 \mathrm{ug} / \mathrm{m}^{3} .9$ Con- 
centrations of cadeiu near cadnium emitting industrial facilities have been found to reach levels of $0.2 ; \mathrm{g} / \mathrm{x}^{3} .41$ Assuming an isinalation rate of $20 \mathrm{~m}^{3} / \mathrm{day}^{53}$ and an absorption rate of $25 \%$, daily cadai= uptake from inhalation would approach a maximo of $1 ; g$. This $1 ; g$ anount is a relatively small fraction $(: 1 \%)$ of the acount salculated as uptake from ingestion of food itens. Industrial exposure is likely to be ach greater in some occupations because the Threshold Liait Value (TLV) for industrial exposure in the United States is $100 ; 9 / \mathrm{m}^{3}$ for cadium funes. 18,19 If we assume an inhalation rate of $10 \mathrm{~m}^{3} / 8 \mathrm{hr}$ working day and that 25: of the inhaled cadmium is absorbed, we can arrive at a daily uptake value of $250 \mathrm{ug}$. An occupational exposure of this agnitude would be of extrewe significance and the TLV itself much too high. Assuming an excretion rate of $0.005 \% / d a y$ and 224 morkdays/year along with the above assumptions, the necessary cadmiu concentration in industrial air for exposed wrkers to accumlate a critical cadmiun concentration in renal cortex of $200 ; g / g$ wet wight at age 50 through inhalation would be 6.5 $-9 / \mathrm{m}^{3}$. For a 50: pulmonary absorption it would be $3.3 \mu \mathrm{g} / \mathrm{m}^{3}$. Recently the American Conference of Governmental and Industrial Hygienists (ACGIH) has recommended a reduction in the ILV for cadmiun to $50 \mu \mathrm{g} / \mathrm{m}^{3}$. 19 The ACGIH recomiendation was set to avoid pulmonary effects and did not consider long term cadaium danage to kidney tissue. An examination of daily intake values wich will result in renal damage over a period of 50 years indicates that the $50 \mu \mathrm{g} / \mathrm{m}^{3}$ occupational exposure level could produce critical levels of cadaiun in hidney tissue even without consideration of other exogenous scurces of cadmiun.

\section{Concentrations in water.}

Surface waters can be contaninated by cadnium fram mine wastes, effluents from electroplating facilities, aírborne particulate deposition, fertilizers and agricultural wastes. In addition, cadinium content of tap water is often increased by contact with galvanized pipes. The permissible level of 0.01 ppm cadnium established by the Public Health Service is used as the 1 imiting value for most considerations. 20 A study conducted by McCate et al. of 969 community water systems showed 
three systems to be in excess of the limiting value. ${ }^{42}$ The maximum concentration was $0.11 \mathrm{ppan}$. At an average daily water consumption of 1.2 liters, ${ }^{43}$ intake of cadmium from water could range up to about 132 ig/day. If we assume that cadmium concentration in drinking water is at the permissible level of $0.01 \mathrm{ppm}$, daily intake from water will be 12 เg.

\section{Concentrations in food}

Normal background levels for cadmium in foods are usually $0.05 \mathrm{Lg} / \mathrm{g}$ wet weight or less. ${ }^{7}$ However, some plants and animals accumulate more cadaiur than others. In calculating daily per capita intake of cadmium via foods, it is, therefore, more realistic to place foods into a number of different categories. Within a given food category, there can be substantial differences in cadmiun concentration anong various fcod itens. Leafy vegetables such a spinach accumulate more cadmium than root vegetables such as carrots. Carrots, in turn, accumulate more cadnium than above-ground vegetables such as string beans. 39 Fulkerson and Goeller reported that cadmiuni concentrations may vary from 0.009 to $0.128 \mathrm{ug} / \mathrm{g}$ for vegetables which are most often eaten. ${ }^{7}$ The average cadiun concentration of Great Lakes fish is $0.044 \mathrm{\mu g} / \mathrm{g}$ wet weight while the average cadniun concentration of fish from 49 other bodies of fresh water is $0.02 \mu \mathrm{g} / \mathrm{g}$. Bioaccumulation factors for cadmium in shellfish are 20 times greater than those for fresh water fish. ${ }^{7,40}$ Cadiium concentrations vary from 0.1 to $7.8 \mathrm{\mu g} / \mathrm{g}$ wet weight in oysters from the East Coast of the U.S. and from 0.2 to $2.1 \mu \mathrm{g} / \mathrm{g}$ in oysters from the West Coast. 9

\section{Cadmium Metabolism in Humans}

\section{Intake and absorption}

The two main human exposure modes to cadmium are through ingestion and inhalation. 7,9 Absorption from the gut is influenced by several factors. In general, absorption of cadmium from the G.I. tract has been 
reported to be about 5 to 6 : with the remainder el iminated primarily in the feces. However, an uptake two or more times greater may occur in individuals with dietary protein deficiency or with a diet low in calcium.

Except for inhalation of cadnium funes by certain industrial workers, the general population is exposed to airborne cadmiun in the form of aerosols. Deposition in the lung will be related to airborne particle size, varying from 10 to 50 ; for particles with dianeters from 0.01 to 5 H. 44 Absorption via the respiratory system is generally considered to be approximately $25 ; .7,9$ for nonoccupationally exfosed persons, cigarette smoking may be the chief source of inhaled cadaium. 9 There appears to be little danger to the general population from exposure to inhaled cadaium.

\section{Transport and distribution}

Whatever the cadnium exposure modes, it will first appear in the bloodstream. Within a few hours there will be a decrease in plasma cadnium levels and an increase in cadmium associated with red cells. 9 Blood concentrations decrease after exposure has ended so that elevated levels of cadmium in blood generally reflect recent exposure. Nordberg et al. found that erythrocytic cadmium was in a fraction corresponding to that of the metal-binding protein metallothionein. 45 Metallothionein (the protein thionine plus a metal) binds cadmium, zinc, mercury, and small amounts of copper and iron due to a high cysteine content. 9

As blood cadnium levels decrease, there is an initial increase in liver concentration. With increasing time after exposure, kidney levels increase and eventually exceed liver concentrations. Even at low levels of continuous exposure cadnium accumulates in the renal cortex, because excretion of the absorbed metal is on an average very low (about 0.005 , of jody burden per day). 19 Cadmiun also accumulates to some extent in pancreas and testes. 7,9

Other metals and compounds can influence metabolism of cadmium. Zinc and cadmium are mutually antagonistic. ${ }^{9,28}$ Presence of calcium will decrease absorption of ingested cadmium. ${ }^{46}$ Selenium dioxide, 
although increasing uptake of cadmive in testes, protected the from drage. 47 It also caused lower levels of cadiug in liver and pancreas wile not affecting kidney levels. Yarious chelating agents can affect cadmiun distribution and toxicity. ${ }^{9}$ metallothionein synthes is is apparently induced by cadwiva and accumlation by kidneys ary be the to reabsorption of metallothione in in remal subules."

then exposure levels reain constant, increase in remal cadium concentrations is almost linear from ages 5 to 50 years. 9 Urinary excretion of cadiun is very low until cadaiu reaches a critical level in kidneys causing renal dysfunction and increased cadaiv excretion. The amount of cadium excreted in feces, anoulting to 90 to 95: of the totai excreted, represents ingested cadmiu wich was not absorbed from the G.I. tract.

Reference $\operatorname{mn}^{43}$ contains on an average about $30 \mathrm{mg}$ of cadniu. 9 About 50: of the total body burden is in liver and kidney with about 33 in kidney alone. The kidney weight of reference man is $300 \mathrm{~g}$. It has been estimated that renal cortex levels are $30^{\circ}$, higher in solkers who smoke a pack of cigarettes a daj for 35 years than in nonsmokers. 9,13

\section{Hean Health Eifects}

Biological response to a pollutant burden ma fall into one of five categories: The pollutant burden (1) may not be associated with a distinct physiological change, (2) way be associated with a change of uncertain significance, (3) my be associated with physiologic changes wich are indicators of specific disease states, (4) may he associated with morbidity, or (5) ma be associated directly with mortality. 48

In discussing health effects of cadmium exposure, we usually describe gross, eastly recognizable responses of the main target organ in relation to dose. Subtle responses at lower levels are not yet fully understood, although there is increasing evidence that such responses occur. Moreover, each toxic pollutant cannot be treated as ail isolated insult since exposure to a number of different pollutants simultaneousiy 
may produce a synergistic effect. This fact should be taken into account whenever possible in evaluating each particular pollutant.

Some tissue and organ responses to a given burden of cadmium can be described. In lung, cadmium aitacks pulmonary epi thel ium and damages alveolar walls, producing bronchitis and emphysema. 49,50 in occupational siidations, high concentrations of cadmium oxide fumes $\left(1 \mathrm{mg} / \mathrm{m}^{3}\right)$ inhaled for as little as 8 hours are considered imrediately dangerous. 9,40 Expusure for longer periods of time to lower concentrations, less than $0.1 \mathrm{mg} / \mathrm{m}^{3}$ of cadmium compounds, can cause chronic pulmonary disorders. ${ }^{9}$ In the G.I. tract, cadmium decreases absorption of such essential elements as caicium, copper, and iron. ${ }^{41}$ Concentrations of 13 to $15 \mathrm{mg} \mathrm{Cd} / \mathrm{s}$ : of drinking fluid produces immediate vomiting and gastrointestinal cramps. Cadmium has been shown to affect hematopoiesis probably because of a deficient absorption of iron from food. This effect can restit in irondeficiency anemia. 41 in the liver, cadmium may cause morphological damage as well as changes in activity of certain enzymes. This may occur for iong-term exposures at moderate leveis and may not show up in clinical diagnostic tests for liver damage. 41 Kidneys accumulate cadmium under conditions of low-level long-term exposure. Renal dysfunction may result if cadnulii in the cortex c::ceeds 200 .g/g wet weight. ${ }^{9}$ The chief ilanifestation of renal $d, j$ function is proteinuria and tubular damage. $7,9,41,49$ It may also be significant that immunoglabulins are excreted during proteinura. Cadmium accumulates in the interstitial tissue of testicles and testicular necrosis may result. ${ }^{47}$ The activity of testosterone may be decreased during long-tem cadmium exposure. ${ }^{41}$ High concentrations of cadmium in the pancreas found during autopsy of cadmium workers indicate the possibility of disturbed function in this organ following exposure to cadmium. ${ }^{9}$

The World Health Organization is now conducting a survey on cardiovascular disedse and trace elements in tissue and in the environment. Enough evidence has been accumulated to indicate a positive correlation between trace elements and hypertension. 51 This effect has been thought to arise at concentrations of radmium in kidneys knlow those producing obvious signs of toxicity. 11 
Cadnium has also been show to produce effects at the molecular level at concentrations below which any obvious symptoms would be exhibited. Arrong these are uncoupling of oxidative phosphorylation and cadnium exchange with $z$ inc in zinc-dependent enzyme systems. $7,9,49$ 


\section{REFERENCES}

1. R. S. Booth, S. V. Kaye, and P. S. Rohwer, "A Systems Analys is Methodology for Predicting Dose to Man from a Radioactively Contaminated Terrestrial Environment," $\because \therefore \therefore \therefore \therefore \therefore \therefore \therefore$ AEC-CONf-710501, (May 10-12, 1971).

2. G. G. Killough and L. R. Mckay, $\because \because 600$ and

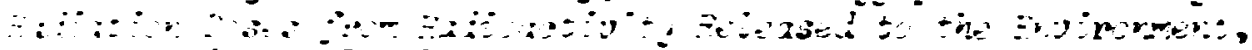
ORNL-4992 (March 1976).

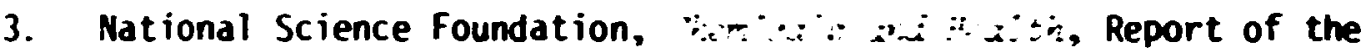
Panel on Chemicals and Health of the President's Science Advisory Committee, Science and Technology Policy Office, Mashington, D.C. (September 1973).

4. M. T. Mills and M. Reeves, $\therefore$ -

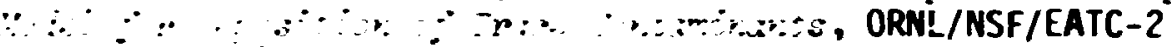
(October 1973).

5. H. V. Culkowski and M. R. Patterson, $\therefore$ re rages

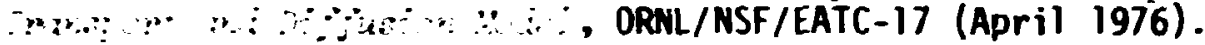

6. S. E. Lindberg, A. H. Andren, R. J. Raridon, and W. Fulkerson, "Mass Balance of Trace Elements in Walker Branch Natershed - The Relation t. Coal Fired Steam Plants," Environ. Health Perspectives $\because$ 9-18 (i975).

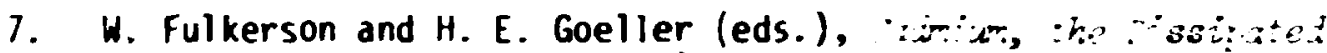
$\because \cdots . \cdots$, ORNL; NSF-EP-21 (1973).

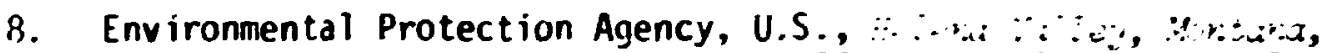

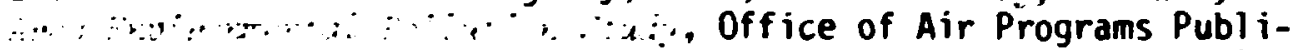
cation No. AP-91, Research Triangle Park, North Carolina (1972).

9. L. Friberg, M. Piscator, G. F. Nordberg, and T. Kjellström, $: \dot{i}:{ }^{m}$. $\because \because \ldots, \cdots \cdots$, , 2nd ed., Chemical Rubber Company, Cleveland, Ohio, 1974.

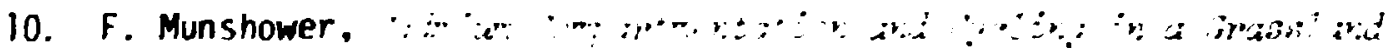

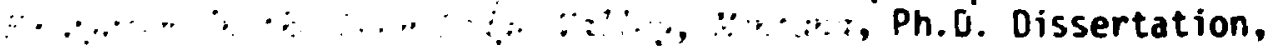
University of Montana, 1972.

11. L. Linnman, A. Andersoon, K. O. Nilsson, B. Lind, T. Kjellström, and L. Friberg, "Cadmium Uptake by Wheat from Sewage Sludge Used as a Plant Nutrient Source," Arch. Environ. Health : 45-47 (1973). 


\section{BLANK PAGE}


12. T. Strenström and H. Lönsjö, "Cadaium Availability of theat: A Study with Radioactive Tracers Under Field Conditions," Abmio z(2): $87-90$ (1974).

13. T. A. Kjellströn, "A Mathematical Model for the Accumslation of Cadaium in Human Kidney Cor tex," Mord. Hyg. Tidskv. s3(2): $111-119$ (1971).

14. R. S. Booth, "A Systems Analysis Model for Calculating Radionucl ide Transport Between Receiving Haters and Botton Sediments," Chapter 7, pp. 133-164 in Envinirme'tal raxicity of Aquatio padionuci ijes:

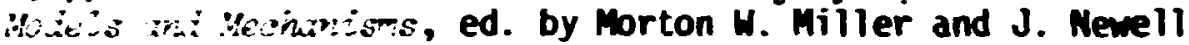
Stannard, Ann Arbor Science Publisiters inc., Ann Arbor, Michigan, 1976.

15. U.S. Department of Agriculture, Agricultural Statistics, Fotal and "er aritu iviizor Consurtition of Foods, 1954-1970, compiled by the U.S. Dept. of Agriculture. Published by the Government Printing Office, Washington, D.C., 1971, Pp. 48, 203, 205, 206, 259, 287,588 .

16. G. K. Murthy, U. Rhea, and J. T. Peeler, "Levels of Antimony, Cadnium, Chromium, Cobalt, Manganese, and Ziric in Institutional Diets," Environ. Sci. and Tech. 5: 436-442 (1971).

17. World Health Organization, Evaiuation of Certain Food Additives ard the? Con:ominants deroury, Lead and tidmium, W.H.O. Tech-Rep. Ser. 505 (1972).

18. American Conference of Governmental and Industrial Hygienists, Documentation: " the Threshoid Limit Values for Substances in Workroom Air, 3rd ed., p. 35, American Conference of Government Industrial Hygienists, Cincinnati, Ohio, 1971.

19. American Conference of Governmental and Industrial Hygienists,

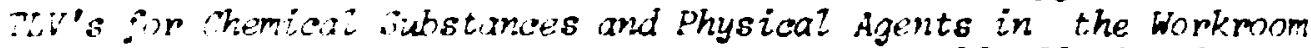
Envimnment ir th irtended timanges for 1973, pp. 12, 36, American Conference of Governmental and Industrial Hygienists, Cincinnati, Ohio, 1973.

20. U.S. Department of Health, Education, and Welfare, Public Feaith 5. mo. Tringing water Stridards, PHS Pub. No. 956, Washington, D.C., 1962.

21. U.S. Department of Commerce, "Summary of Hourly Observations,

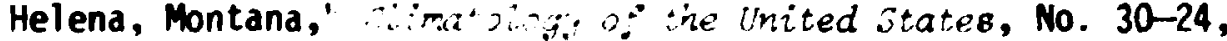
U.S. Department of Commerce, Washington, D.C., 1956.

22. National Oceanographic and Atmospheric Administration, Climates of - $\because: \because$ Vol. 2, p. 755, Water Information Center, National Oceanographic and Atmospheric Administration, Port Washington, New York, 1974. 
23. F. Harris, A. Andren, and G. Henderson, "Trace Elenents from Coal-

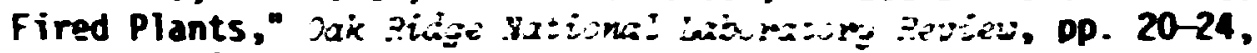
Spring, 1975.

24. D. H. Klein et al., "Pathays of 37 Trace Elements through CoalFired Power Plants," Environ. Sci. and Tech. :: $973-979$ (1975).

25. R. L. Davison, D.F.S. Matusch, and J. R. Wall lace, "Trace Elements in Fly Ash. Dependence of Concentration on Particle Size," Environ. Sci. and Tech. 3: 1107-1113 (1974)

26. H. A. Schroeder and J. J. Balassa, "Cadmiun: Uptake by Vegetable from Superphesphate in Soil," Science 140: 819-820 (1973).

27. U.S. Department of Comerce, Statistinat Ats:racts of the $\because .$. , , National Data Book and Guide to Sourzes, U.S. Departiment of Camerce, Social and Economic Statistics Adainistration Bureau of the Census, Washington, D.C., 1974.

28. H. A. Schroeder, A. P. Mason, I. H. Tipton, and J. J. Balassa, "Essential Trace Elements in Man: Zinc in Relation to Environmental Cadmium," J. Chronic Dis. 20: 179-2io (1967).

29. E.M.D. Huffman, Jr., and J. F. Hodgson, "i)istribution of Cadmiun and Zinc/Cadmium Ratios in Crops from 19 States East of the Rocky Mountains," J. Environ. Qual. 2(2): 289-291 (1973).

30. T. Strenström and M. Yohter, "Cadmium and Lead in Swedish commercial Fertilizers," Ambio 3(2): 91-92 (1974).

31. R. G. Ross and D.K.R. Stewart, "Cadmica Residue. in Apple Fruit and Fol iage Following a Cover Spray of Cadmium Chloride," Can. J. Plant Sci. 49: 49-52 (1969).

32. M. K. John, "Cadmiun Uptake by Eight Food Crops as Influenced by Various Soil Levels of Cadmiun," Environ. Pollut. 4: 1-15 (1973).

33. M. K. John, "Uptake of Soil-Applied Cadmiun and its Distribution in Radishes," Can. J. Plant Sci. Sa: 715-719 (1972a).

34. M. K. John, "Factors Affecting Plant Uptake and Phytotoxicity of Cadnium Added to Soils," Envíron. Sci. and Tech. f(12): 1005-1009 (1972b).

35. G. 'AcGrath, "Chemicals for Plant Disease Control," Agri. Chem. :.: 18-37 (1964).

36. K. K. Hychoff and J. E. Guthrie, "Methods of El iminating Helminths with Cadmium Compounds," U.S. Patent Office Gaz. in: 295 (1965). 
37. M. Ulrychova-Zelinkova, "Cadmiun Ions as Inhibitors of Tobacco mosaic Virus," Biol. Plantarum :(2): 135-141 (1959).

38. P. Little and M. H. Martin, "A Survey of Zinc, Lead, and Cadnium in Soil and Matural Vegetzion Around a Smelting Complex," Environ. Pollut. a: 241-254 (1972).

39. D. D. Heaphill, "Availability of Trace Elements to Plants with Respect to Soil-Plant Interaction," N.Y. Acad. of Sci. Ann. 199: 46-51 (1972).

40. A. Ishizaki, M. Fukushima, and M. Sakamoto, "Oistribution of Cadaiu in Biological Materials, Part 2. Cadaiun and Zinc Contents of Foodstuffs," Jap. J. Hyg. Ex: 207-222 (1970).

41. G. F. Nordberg, "Health Hazards of Environnental Cadnium Pollution," Ambio $3(2)$ : 55-56 (1974).

42. L. J. Mclabe, J. M. Symons, R. O. Lee, and G. G. Roebuck, "Survey of Comunity Hater Supply jystems," J. Aner. Mater Horks Assoc. 62: $670(1970)$.

43. Internitional Comission on Radiological Protection, Report: the Task Grou: on Rejerence :Aan, ICRP Publication No. 23, Pergamon Press, New York, 1975.

44. Task Group on Lung Dynamics, "Deposition and Retention Models for Internal Dosimetry of the Human Respiratory Tract," Health Phys. $\therefore$ : 173-207 (1966).

45. G. F. Norberg, M. Piscator, and B. Lind, "Distribution of Cadmium among Protein Fractions of Mouse Liver," Acta Pharmacol. Toxicol. s. $456(1971)$.

46. H. A. Schroeder, A. P. Mason and J. J. Balassa, "Trace Metals in Rat Tissues as Influenced by Calcium in Hater," J. Nutr. :3: 331-336 (1967).

47. S. A. Gunn, T. C. Gould, and H.A.D. Anderson, "Mechanisms cf Zinc, Systeine, and Selenium Protection Against Cadnium-Induced Vascular Injury to Mouse Testes," J. Reprod. Fertil. 15: 65-70 (1968).

48. J. T. Finklea, D. J. Hammer, T. A. Himners, and C. Pinkerton,

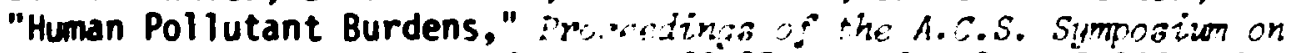

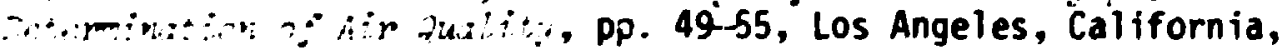
Apri1 1-2, 1971

49. G. Buell, "Some Biochemical Aspects of Cadmium Toxicology," J. Occupational Med. :?: 189-195 (1975). 
50. G. P. Lewis, H. Lyle, and S. Miller, "Association Between Elevated Hepatic Mater-Soluble Protein-Bound Cadmium Levels and Chronic Bronchit is and/0: Emphysea," The Lancet : : 1339-1333 (1969).

51. H. A. Schroeder, "The Role of Trace Elenents in Cardiovascular Diseases," Medical Clinics of North America $: \equiv(2)$ : $381-396$ (1974).

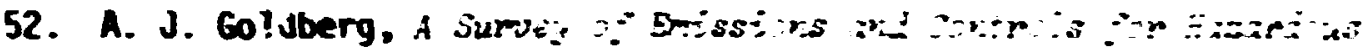

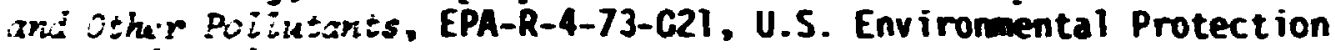
Agency (i973).

53. International Comission on Radiological Protection, $\because: \cdots:$

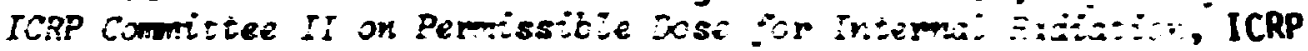
Publication 2, Perganon Press, New Yorik, 1959.

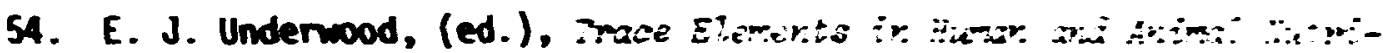
ticr., 3rd ed., PD. 267-280, Institute of Agriculture, University of Western Australia, Nedlands, Mestern Australia, Academic Press, New York and London, 1971.

55. R. Ratu and A. Sporn, "Contributions to the Determination of Cadaium Supplied by Foods," Mahrung ::: 25-31 (1970). 